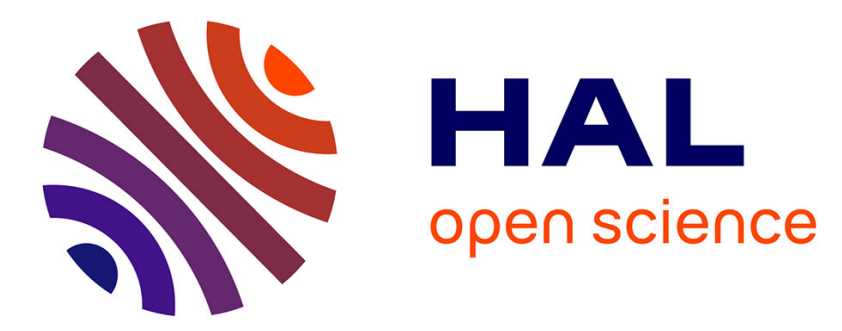

\title{
Pleistocene herbivores and carnivores from France: An updated overview of the literature, sites and taxonomy
}

Jean-Philip Brugal, Alain Argant, Myriam Boudadi-Maligne, Evelyne

Crégut-Bonnoure, Roman Croitor, Philippe Fernandez, Jean-Baptiste Fourvel, Philippe Fosse, Jean-Luc Guadelli, Bruno Labe, et al.

\section{To cite this version:}

Jean-Philip Brugal, Alain Argant, Myriam Boudadi-Maligne, Evelyne Crégut-Bonnoure, Roman Croitor, et al.. Pleistocene herbivores and carnivores from France: An updated overview of the literature, sites and taxonomy. Annales de Paléontologie, 2020, 106 (2), pp.102384. 10.1016/j.annpal.2019.102384 . hal-03017462

\section{HAL Id: hal-03017462 \\ https://hal.science/hal-03017462}

Submitted on 20 Nov 2020

HAL is a multi-disciplinary open access archive for the deposit and dissemination of scientific research documents, whether they are published or not. The documents may come from teaching and research institutions in France or abroad, or from public or private research centers.
L'archive ouverte pluridisciplinaire HAL, est destinée au dépôt et à la diffusion de documents scientifiques de niveau recherche, publiés ou non, émanant des établissements d'enseignement et de recherche français ou étrangers, des laboratoires publics ou privés. 
Original article

\section{Pleistocene herbivores and carnivores from France: An updated overview of the literature, sites and taxonomy}

Herbivores et carnivores pléistocènes en France : bilan général récent bibliographique, des gisements et de la taxinomie Jean-Philip Brugal $^{\mathrm{a}, *}$, Alain Argant ${ }^{\mathrm{a}}$, Myriam Boudadi-Maligne ${ }^{\mathrm{b}}$, Evelyne Crégut-Bonnoure ${ }^{\mathrm{c}}$, Roman Croitor ${ }^{\mathrm{a}}$, Philippe Fernandez ${ }^{a}$, Jean-Baptiste Fourvel ${ }^{a}$, Philippe Fosse ${ }^{a}$, Jean-Luc Guadelli ${ }^{b}$, Bruno Labe ${ }^{a}$, Pierre Magniez ${ }^{a}$, Antigone Uzunidis ${ }^{\text {a }}$

a Aix-Marseille Université, CNRS, Minist. Culture, UMR 7269 Lampea, MMSH, 13094 Aix-en-Provence cedex 2, France

b PACEA-UMR5199 CNRS, Université de Bordeaux, Bât. B2, Allée Geoffroy-Saint-Hilaire, CS50023, 33615 Pessac cedex, France

${ }^{\mathrm{c}}$ Muséum Requien, 67, rue Joseph-Vernet, 84000 Avignon, France

\section{A R T I C L E IN F O}

\section{Article history:}

Received 14 January 2019

Accepted 18 November 2019

Available online $\mathrm{xxx}$

\section{Keywords:}

France

Pleistocene

Herbivores

Carnivores

Sites

Taxonomy

Bibliography

Mots clés:

France

Pléistocène

Herbivores

Carnivores

Gisements

Taxinomie

Bibliographie

\begin{abstract}
A B S T R A C T
This contribution presents a general account and summary of the research carried out over the past decades on the Quaternary faunas of France. This country is located in the center of Western Europe, and presents distinct topographical features and very varied climatic influences. This paper is the result of collaborative work between French teams and different researchers specialized in the paleontology of large mammals. Over a hundred paleontological or archaeological sites are mentioned in this review, which covers a broad chronological period, ranging from the Early (including the end of Pliocene/Gelasien) and Middle Pleistocene to the Late Pleistocene. One of the aims of this work is to present studies of the main families or subfamilies of herbivores (Equidae, Rhinocerotidae, Bovidae [Bovines, Caprines, Antilopines, and Rupicaprines], Cervidae, Proboscid) and carnivores (Canidae, Ursidae, Mustelidae, Hyenidae, Felidae). It is not exhaustive at the generic and specific level, but details on the taxonomic status, evolutionary levels and biochronological importance of the most important taxa are given alongside an extensive and up-to-date bibliography of French works.
\end{abstract}

R É S U M É

Cette contribution expose un bilan général et synthétique des recherches menées ces dernières France sur les faunes Quaternaires de ce pays situé au centre de l'Europe de l'Ouest, avec une topographie et des influences climatiques très variées. Cet article est le résultat d'un travail collectif entre différents spécialistes et équipes françaises en Paléontologie des grands mammifères. Près d'une centaine de gisements, paléontologiques ou archéologiques sont concernés et couvrent une large période, depuis la fin du Pliocène, le Pléistocène inférieur et moyen jusqu'au Pléistocène supérieur. Un des buts du travail est de présenter les études réalisées sur les principales familles ou sous-familles d'herbivores (Equidés, Rhinocérotidés Bovidés [Bovinés, Caprinés, Antilopinés, Rupicaprinés] Cervidés, Proboscidiens) et de carnivores (Canidés, Ursidés, Mustélidés, Hyénidés, Félidés). Sans être exhaustif au niveau générique et spécifique, des précisions sur le statut taxonomique, les degrés évolutifs et l'importance biochronologique des taxons sont présentées, accompagnées d'une bibliographie abondante et à jour des travaux français.

(C) 2019

\section{Introduction}

France is a distinct geographical area at the crossroads of several northern and southern European countries with diverse climatic influences (oceanic, semi-continental, Mediterranean, mountainous) and

\footnotetext{
* Corresponding author.

Email address: brugal@mmsh.univ-aix.fr (J-P Brugal)
}

a varied topography and river systems. At times, during the course of the Quaternary, these elements conditioned specific animal communities, as a result of the combination of these diverse influences in relation with the overall structure of mammal communities in the Western Eurasiatic region (Brugal and Croitor, 2007). In this contribution, we present an overview and an assessment of research on the main groups of herbivores and carnivores from French archaeological and paleontological sites, alongside a relatively exhaustive bibliography of the studies carried out to date in France. 


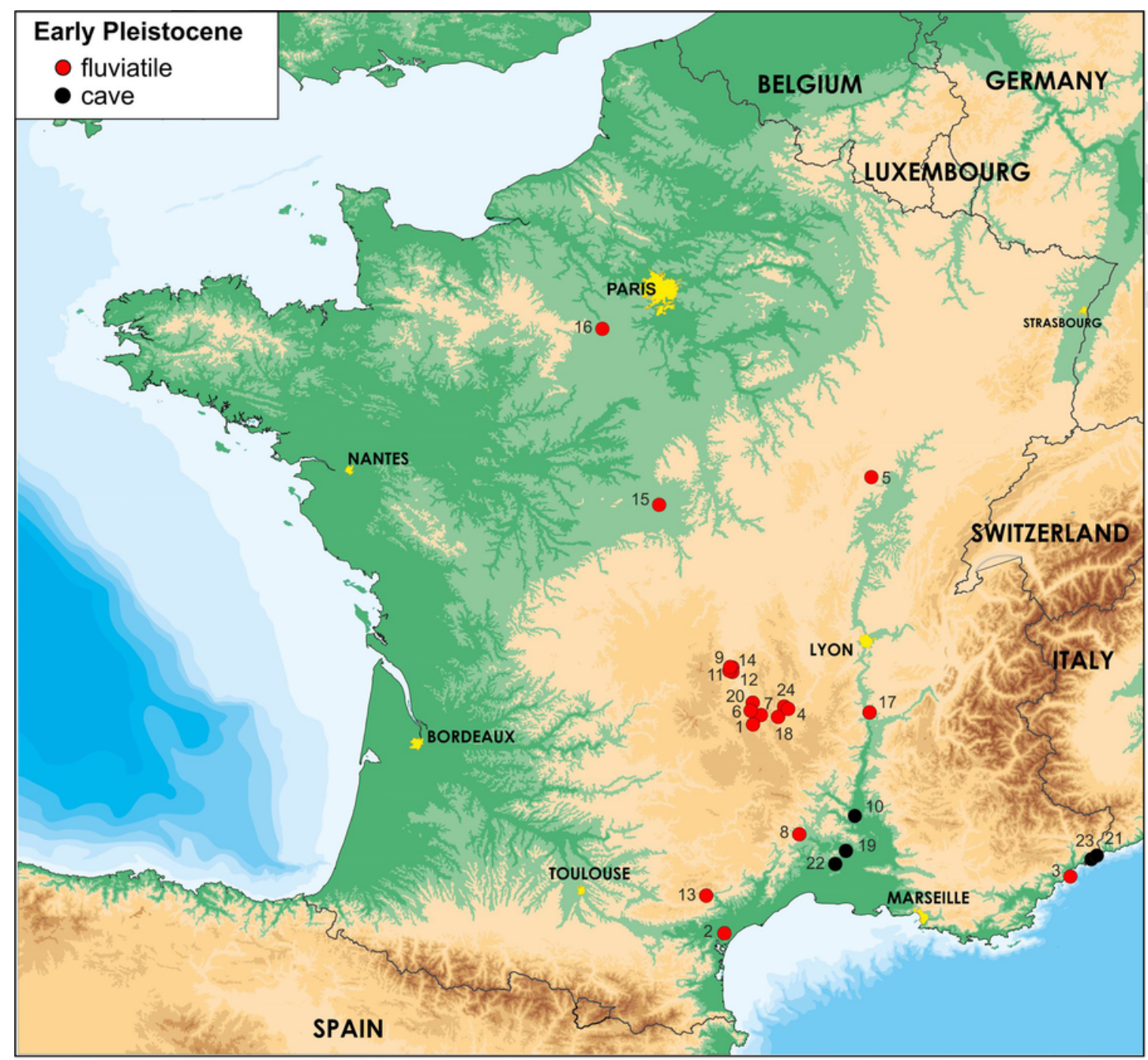

1 - Blassac la Girondie ; 2 - Bois de Riquet ; 3 - Cagnes sur Mer ; 4 - Ceyssaguet ; 5 - Chagny ; 6 - Chilhac ; 7 - Coupet, Le ; 8 - Durfort ; 9 - Etouaires, Les ; 10 - Grosse Marguerite ; 11 - Pardines ; 12 - Peyrolles ; 13 - Riège ; 14 - Roccaneyra ; 15 Rozières; 16 - Saint Prest; 17 - Saint Vallier ; 18 - Sainzelles; 19 -Sartanette, La ; 20 - Senèze ;21 - Tour de Grimaldi ; 22 Trois Pigeons, aven des; ; 23 -Vallonnet, Le;24-Vialette.

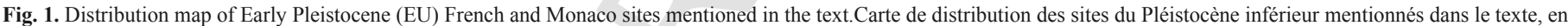
France et à Monaco.

\section{Material and presentation of sites}

Over a hundred sites ( $n=106$, Figs. $1-3)$ are cited in this contribution, with the following chronological distribution: $22.6 \%$ of the sites are from the Early Pleistocene (including the end of Pliocene/ Gelasien), $39.6 \%$ and $37.7 \%$ are from the Middle and Upper Pleistocene respectively. These are the most important sites, but this number could be multiplied by at least 20, in particular for the most recent periods, associated with Middle and Upper Palaeolithic human occupations. Generally speaking, archaeofaunas yield more fragmented and limited material, which are less suitable for paleontological analysis. The natural sites, such as sinkholes or dens, yield more complete fossil remains, often with higher numbers of individuals ('population' structure, herbivores and carnivores) and are usually more taxinomically diversified. Most of the Early Pleistocene sites are open-air sites (from diverse sedimentary contexts: lacustrine, fluvial, aeolian..., 75\%), but karstic cavities (caves, sinkholes, rock shelters) subsequently become predominant (71.4\% and $92.5 \%$, during the Middle and Upper Pleistocene respectively). There is a higher concentration of Early Pleistocene sites in the Massif Central, a higher altitude region in the center of France, whereas the Middle and tate Pleistocene sites are more heavily concentrated in the southern half of the country with sites mostly located between plains (around the major hydrological basins, such as the Rhône and Garonne rivers) and highlands (Massif Central, Pyrenees, Alpes, Jura).

In this contribution we will first outline the mammal species identified in France, and then go into more detail on some recently studied taxa, complemented by a comprehensive review of the literature of mainly French studies. Maps showing precise site location and some chronological dates are given, although the exact geochronological chart and duration/presence of taxa and evolutionary lineages still needs to be by marine isotopic stage (MIS: Table 1), shows to some extend estimates, especially in the case of the Early Pleistocene sites. For this period, the time ranges are broad, covering several climatic stages 


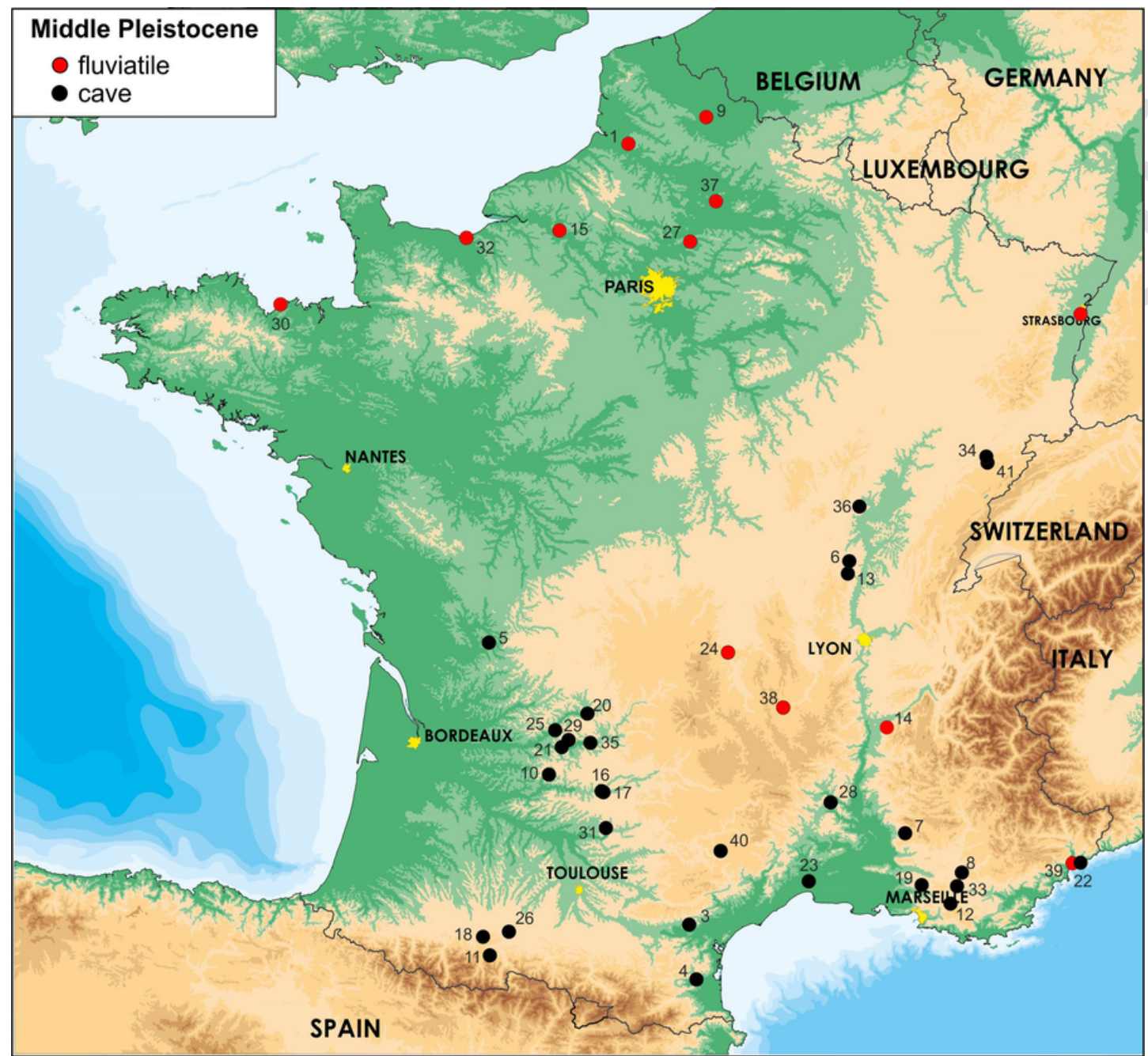

1 - Abbeville ; 2 -Achenheim ; 3 - Aldène ; 4 - Arago ; 5 - Artenac ; 6 - Azé ; 7 - Bau de l'Aubesier ; 8 Baume Bonne ; 9 -Biache Saint Vaast ; 10 - Camp de Peyre ; 11 - Cap de la Bielle ; 12 - Cèdres, Les ; 13 - Château ; 14 - Châtillon Saint Jean ; 15 - Cléons ; 16 - Coudoulous I; 17 - Coudoulous II ; 18 Es-Taliens ; 19 - Escale, L' ; 20 - Fage I, La ; 21- grotte XV (Vaufrey) ; 22 - Lazaret ; 23 - Lunel-Viel ; 24- Malbattu ; 25 - Micoque, La ; 26 - Montmaurin La Niche ; 27 - Moru ; 28 - Orgnac 3 ; 29 - Pech de I'Aze II ; 30 - Piégu ; 31 - Rameaux, Les ; 32 - Ranville ; 33 - Rigabe ; 34 - Romain la Roche ; $\mathbf{3 5}$ Saint Sol Belcastel ; 36 - Santenay ; 37 - Sempigny ; 38 - Soleilhac ; 39 - Terra Amata ; 40 Vayssière, La; 41 - Vergranne.

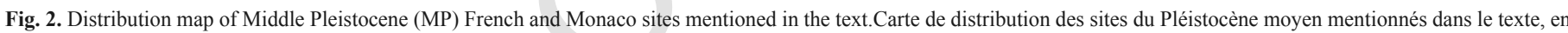
France et à Monaco.

but even if we cannot precise their exact dates (and climatic phases), they are relevant as a general order in the chronological succession of sites. The deposits of the second half of the Middle Pleistocene and of the Late Pleistocene are more often associated with radiometric dating's (OSL, U/Th, 14C...) and then present a better time frame resolution. It is notably reliable for the end of Late Pleistocene, allowing to finely correlate faunal associations with certain climatic events, such as Heinrich or D-O events, within MIS 3 to 1, range of the $14 \mathrm{C}$ datings. Most of these sites are karstic cavities, which sometimes yield thick sedimentary multilayered sequences covering several isotopic stages and climatic phases. Due to these dating uncertainties, the local fauna dynamics in the context of global Quaternary climatic changes will not be discussed here, as it is beyond the scope of the present contribution. The French record corresponds to south- western European biomes and reveals the set-up of modern-type Pleistocene faunal associations from the Middle Pleistocene, coincident with the onset and subsequent amplification of high-latitude glacial cycles (onset of $100 \mathrm{kyr}$ cycle from around $1 \mathrm{My}$ ) (Bonifay, 1996a, b; Bonifay and Brugal, 1996; Croitor and Brugal, 2001; Brugal and Croitor, 2007). Nevertheless, a biochronological chart is presented based on the Pleistocene subseries/subepochs (Table 1). The systematic order is the following: Perissodactyles (Equids, Rhinocerotids), Artiodactyles (Bovids, Cervids), Proboscids, Caniforms (Canids, Ursids, Mustelids) and Feliforms (Hyenids, Felids). Other large mammal groups (Suids, Hippotamids) are not considered here as any recent works has been done on these groups, and we refer readers to Guérin and Patou-Mathis (1996) among them. Among the taxa, some are more likely to provide biochronological indica- 


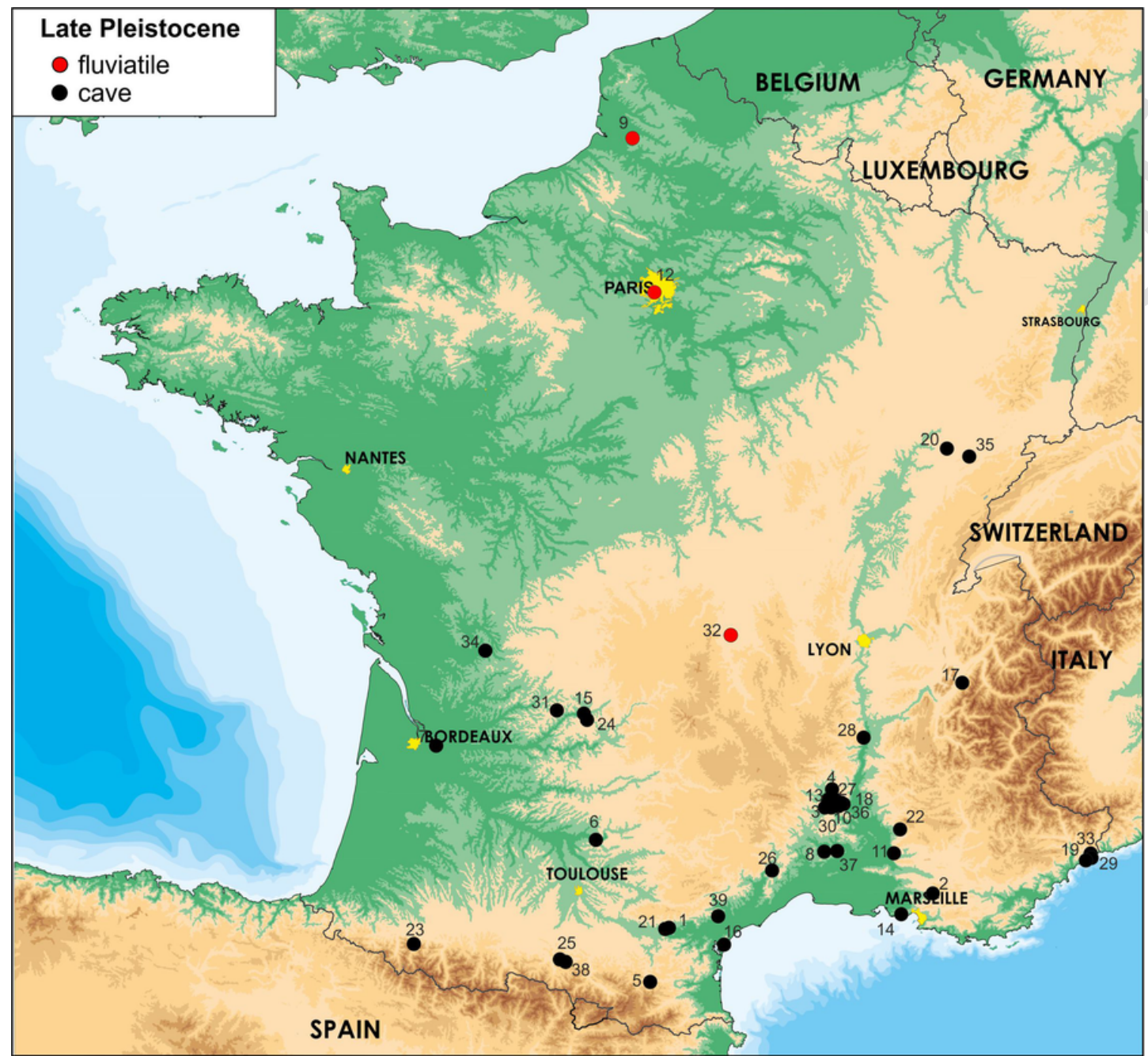

1 - Abeurador ; 2 - Adaouste ; 3 - Arquet, L'; 4 - Balazuc ; 5 - Belvis ; 6 - Bruniquel ; 7 - Camiac ; 8 Campefiel ; 9 - Caours ; 10 - Chabot ; 11 - Chinchon ; 12 - Closeau, Le ; 13 - Colombier, Le ; 14 Cornille ; 15 - Coustal, Le ; 16 - Crouzade, La ; 17 - Cuvée des Ours ; 18 - Dumas ; 19 - Enfants, Les ; 20 - Fouvent;21 - Gazel; 22 - Grand Abri aux Puces; 23 - Habarra ; 24 - Jaurens ; 25 - Malarnaud ; 26 - Marie ; 27 - Marronnier, Le ; 28 - Moula Guercy ; 29 - Observatoire ; 30 - Oullins ; 31 - Peyrat, Le ; 32 - Pont du Château ; 33 - Prince ; 34 - Queroy, Le ; 35 - Rigney ; 36 - Saint Marcel d'Ardèche ; 37 Salpétrière, La; 38 -Soulabé ; 39 -Tournal.

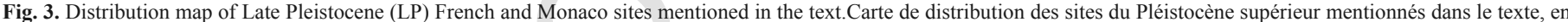
France et à Monaco.

tions, based on evolutive stage, as in the Equids or large Bovids, but also in Caprines, Canids and some felines and bears.

\section{Perissodactyles}

\subsection{Equidae}

\subsubsection{Stenonians and Caballines}

Work on horses can be grouped into two sets: paleontological case studies and more general studies on morphology and adaptive traits, phylogeny, DNA, structure of populations, zooarchaeology and domestication, which are totally or partly based on fossils from French sites. Some case studies include that of Equus stenonis from Vallonnet (Moullé, 1992; Moullé et al., 2006a), but they mostly represent caballine Equids in the broad sense of the term (see
Supplementray Informations for latin terminology). This is the case for Equus mosbachensis ssp., a more typical Middle Pleistocene form, and the different subspecies described; $E$. m. campdepeyri (Camp-de-Peyre, Fig. 4), E. m. micoquii (La Micoque), E. m. palustris (Lunel-Viel, Rigabe), E. m. tautavelensis (Caune de l'Arago) (Bonifay, 1980; Crégut Bonnoure, 1980; Eisenmann et al., 1985; Guadelli and Prat, 1983; Bellai, 1998; Langlois, 2005; Uzunidis-Boutillier, 2017). Several studies have provided information on more problematic taxa, such as Equus achenheimensis, identified in particular at Achenheim and Romain-la-Roche (Eisenmann, 1991a; Boulbes, 2010), Equus steinheimensis, for example at Châtillon-Saint-Jean (Eisenmann, 1998) and Equus taubachensis, represented for example at Bau de l'Aubesier and Biache-Saint-Vaast (Auguste, 1995; Fernandez, 2006; Crégut-Bonnoure et al., 2010). For Caballines, in the strict sense of the term studies have focused on Equus caballus piveteaui, $\equiv$ defined 
Table 1

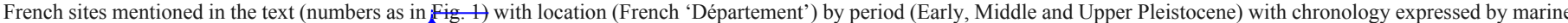

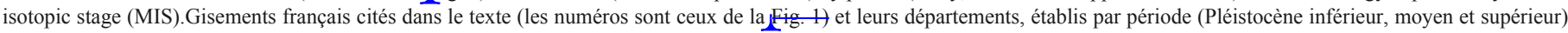
et chronologie suivant les stades isotopiques marins (SIM).

\begin{tabular}{|c|c|c|c|c|c|c|c|c|c|c|c|}
\hline \# & MIS & Sites & Département & \# & MIS & Sites & Département & \# & MIS & Sites & Département \\
\hline \multicolumn{4}{|c|}{ Early Pleistocene } & \multicolumn{4}{|c|}{ Middle Pleistocene } & \multicolumn{4}{|c|}{ Upper Pleistocene } \\
\hline 1 & $24-21$ & $\begin{array}{l}\text { Blassac-la- } \\
\text { Girondie }\end{array}$ & Haute-Loire & 1 & $15-13$ & Abbeville & Somme & 1 & 2 & $\begin{array}{l}\text { Abeurador, } \\
\text { Balma }\end{array}$ & Hérault \\
\hline 2 & $30-27$ & Bois-de-Riquet & Hérault & 2 & $\begin{array}{l}\text { Middle- } \\
\text { late }\end{array}$ & Achenheim & Bas Rhin & 2 & $5 \& 2$ & Adaouste & $\begin{array}{l}\text { Bouches-du- } \\
\text { Rhône }\end{array}$ \\
\hline 3 & Late & $\begin{array}{l}\text { Cagnes-sur- } \\
\text { Mer }\end{array}$ & $\begin{array}{l}\text { Alpes- } \\
\text { Maritimes }\end{array}$ & 3 & $10-9$ & Aldène & Hérault & 3 & $3-2$ & Arquet, L' & Ardèche \\
\hline 4 & $36-34$ & Ceyssaguet & Haute-Loire & 4 & $16-5$ & Arago & $\begin{array}{l}\text { Pyrénées- } \\
\text { Orientales }\end{array}$ & 4 & $3-2$ & Balazuc II & Ardèche \\
\hline 5 & Late & Chagny & $\begin{array}{l}\text { Saône-et- } \\
\text { Loire }\end{array}$ & 5 & Late & Artenac & Charente & 5 & 2 & Belvis & Aude \\
\hline 6 & $74-72$ & Chilhac & Haute-Loire & 6 & $9-6$ & Azè & Saône-et-Loire & 6 & 2 & Bruniquel & $\begin{array}{l}\text { Tarn-et- } \\
\text { Garonne }\end{array}$ \\
\hline 7 & $70-68$ & Coupet, Le & Haute-Loire & 7 & $7-6(5)$ & $\begin{array}{l}\text { Bau de } \\
\text { l'Aubesier }\end{array}$ & Vaucluse & 7 & 3 & Camiac & Gironde \\
\hline 8 & $26-24$ & Durfort & Gard & 8 & $7-6$ & Baume Bonne & $\begin{array}{l}\text { Alpes-de-Haute- } \\
\text { Provence }\end{array}$ & 8 & 2 & Campefiel & Gard \\
\hline 9 & $92-86$ & Etouaires & $\begin{array}{l}\text { Puy-de- } \\
\text { Dôme }\end{array}$ & 9 & $7-6$ & $\begin{array}{l}\text { Biache-saint- } \\
\text { Vaast }\end{array}$ & Pas-de-Calais & 9 & 5 & Caours & Somme \\
\hline 10 & Late? & $\begin{array}{l}\text { Grosse } \\
\text { Marguerite }\end{array}$ & Gard & 10 & 12 & Camps-de-Peyre & Lot-et-Garonne & 10 & $3-2$ & Chabot & Gard \\
\hline 11 & $36-35$ & Pardines & $\begin{array}{l}\text { Puy-de- } \\
\text { Dôme }\end{array}$ & 11 & 6 & Cap de la Bielle & Hautes-Pyrénées & 11 & 2 & Chinchon I & Vaucluse \\
\hline 12 & $32-30$ & Peyrolles & $\begin{array}{l}\text { Puy-de- } \\
\text { Dôme }\end{array}$ & 12 & 6 & Cèdres, Les & Var & 12 & 2 & Closeau, Le & Hauts-de-Seine \\
\hline 13 & $44-40$ & Riège & Hérault & 13 & $\begin{array}{l}15-14 \text { et } \\
6\end{array}$ & Château & Saône-et-Loire & 13 & 2 & Colombier, Le & Ardèche \\
\hline 14 & $86-82$ & Roccaneyra & $\begin{array}{l}\text { Puy-de- } \\
\text { Dôme }\end{array}$ & 14 & $9-7$ & $\begin{array}{l}\text { Chatilllon-Saint- } \\
\text { Jean }\end{array}$ & Drôme & 14 & 2 & Cornille & $\begin{array}{l}\text { Bouches-du- } \\
\text { Rhône }\end{array}$ \\
\hline 15 & $28-26$ & Rosières & Cher & 15 & 9 & Cléon & Seine-Maritime & 15 & $(6)-5$ & Coustal, Le & Lot \\
\hline 16 & $28-26$ & Saint-Prest & Eure-et-Loir & 16 & $7-6$ & Coudoulous I & Lot & 16 & $3-2$ & Crouzade, La & Aude \\
\hline 17 & $85-84$ & Saint-Vallier & Drôme & 17 & $6-4$ & Coudoulous II & Lot & 17 & $3-2$ & Cuvée des Ours & Isère \\
\hline 18 & $44-39$ & Sainzelle & Haute-Loire & 18 & $12-10$ & Es-Taliens & Hautes-Pyrénées & 18 & 2 & $\begin{array}{l}\text { Dumas (Saut du } \\
\text { Loup) }\end{array}$ & Gard \\
\hline 19 & $28-26$ & Sartanette & Gard & 19 & $19-16$ & Escale, L' & Bouches-du-Rhône & 19 & $5-3$ & Enfants, Les & Monaco \\
\hline 20 & $77-76$ & Senèze & Haute-Loire & 20 & $9-7$ & Fage I, La & Corrèze & 20 & 4 & Fouvent & Haute-Saône \\
\hline 21 & $29-27$ & $\begin{array}{l}\text { Tour-de- } \\
\text { Grimaldi }\end{array}$ & Monaco & 21 & $8-6$ & $\begin{array}{l}\text { Grotte XV } \\
\text { Vaufrey }\end{array}$ & Dordogne & 21 & 2 & Gazel & Aude \\
\hline 22 & Late? & Trois Pigeons & Gard & 22 & $8-6$ & Lazaret & Alpes-Maritimes & 22 & $5 \mathrm{e}$ & $\begin{array}{l}\text { Grand Abri aux } \\
\text { Puces }\end{array}$ & Vaucluse \\
\hline 23 & $28-26$ & Vallonnet, Le & $\begin{array}{l}\text { Alpes- } \\
\text { Maritimes }\end{array}$ & 23 & $9-8$ & Lunel-Viel & Hérault & 23 & $3-2$ & Habarra & $\begin{array}{l}\text { Pyrénées- } \\
\text { Atlantiques }\end{array}$ \\
\hline \multirow[t]{18}{*}{24} & $\begin{array}{l}\text { ca. } 3 \\
\text { My }\end{array}$ & Vialette & Haute-Loire & 24 & Early & Malbattu & Puy-de-Dôme & 24 & 3 & Jaurens & Corrèze \\
\hline & & & & 25 & $10-8$ & Micoque, La & Dordogne & 25 & 3 & Malarnaud & Ariège \\
\hline & & & & 26 & $7-(5)$ & Montmaurin-La & Haute-Garonne & 26 & 3 & Marie & Hérault \\
\hline & & & & 27 & Late & Moru & Oise & 27 & $3-2$ & Marronnier, Le & Ardèche \\
\hline & & & & 28 & $9-7$ & Orgnac III & Ardèche & 28 & $(6) 5-4$ & Moula Guercy & Ardéche \\
\hline & & & & 29 & 6 & Pech de l'Azé II & Dordogne & 29 & (7) $5-3$ & Observatoire, L' & Monaco \\
\hline & & & & 30 & $6-5$ & Piégu & Côtes d'Armor & 30 & $3-2$ & Oullins & Ardèche \\
\hline & & & & 31 & $9-7$ & Rameaux, Les & Tarn-et-Garonne & 31 & 2 & Peyrat & Dordogne \\
\hline & & & & 32 & 6 & Ranville & Calvados & 32 & $5-4$ & Pont-du-Château & Puy-de-Dôme \\
\hline & & & & 33 & 6 & Rigabe & Var & 33 & $5-3$ & Prince & Monaco \\
\hline & & & & 34 & 6 & $\begin{array}{l}\text { Romain-la- } \\
\text { Roche }\end{array}$ & Doubs & 34 & 2 & Quéroy, Le & Charente \\
\hline & & & & 35 & Late & $\begin{array}{l}\text { Saint-Sol- } \\
\text { Belcastel }\end{array}$ & Lot & 35 & 2 & Rigney & Ain \\
\hline & & & & 36 & $6-5$ & Santenay & Côte-d'Or & 36 & $4-3$ & $\begin{array}{l}\text { Saint-Marcel } \\
\text { d'Ardèche }\end{array}$ & Ardèche \\
\hline & & & & 37 & Late & Sempigny & Oise & 37 & $3-2$ & Salpêtrière, La & Gard \\
\hline & & & & 38 & $19-17$ & Soleilhac & Haute-Loire & 38 & 2 & Soulabé & Ariège \\
\hline & & & & 39 & $11-10$ & Terra Amata & Alpes-Maritimes & 39 & $4-2$ & Tournal & Aude \\
\hline & & & & 40 & $16-18$ & Vayssiere, La & Aveyron & & & & \\
\hline & & & & 41 & $16-15$ & Vergranne & Doubs & & & & \\
\hline
\end{tabular}

at Abri-Suard (Griggo, 1995; Guadelli, 2007; Uzunidis-Boutillier, 2017), and E. c. germanicus, gallicus and arcelini, which are almost always represented in Upper Pleistocene sites (Eisenmann,
1988; Guadelli, 1989a, 1991, 1995; Eisenmann and David, 1990, 2002; Bignon, 2003; Fabre, 2017).

More general work focus on morphology: identification keys for teeth and different skeletal elements, adaptive characters to the envi- 


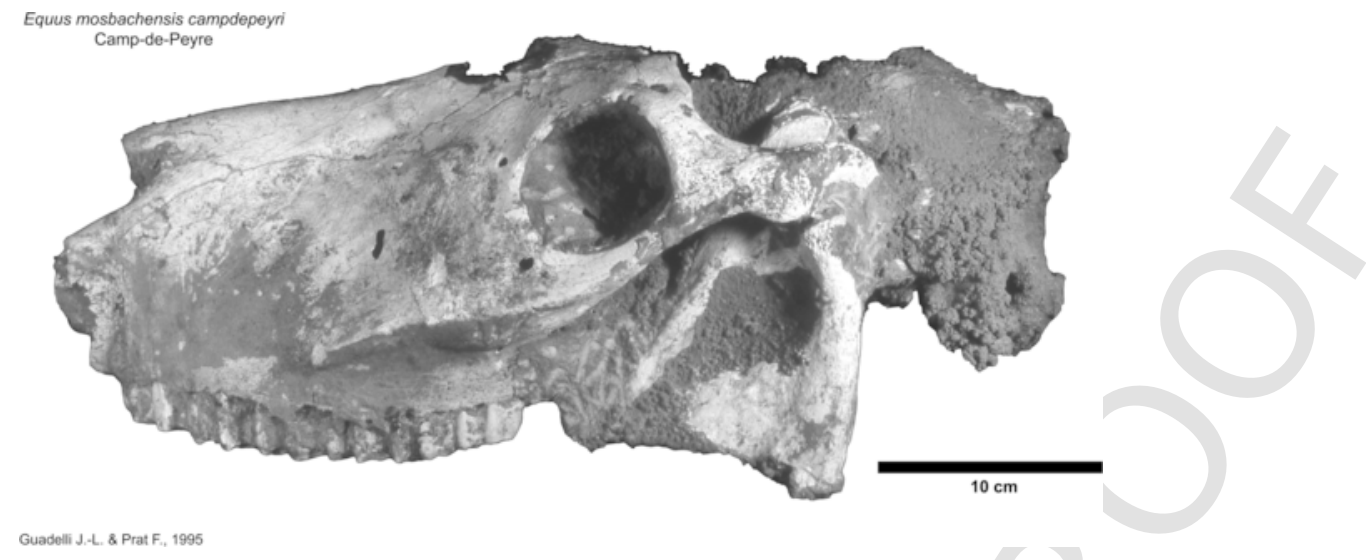

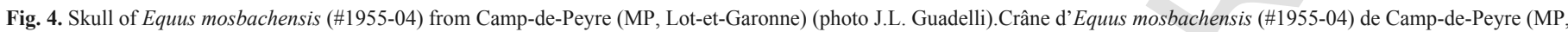
Lot-et-Garonne) (photo J.L. Guadelli).

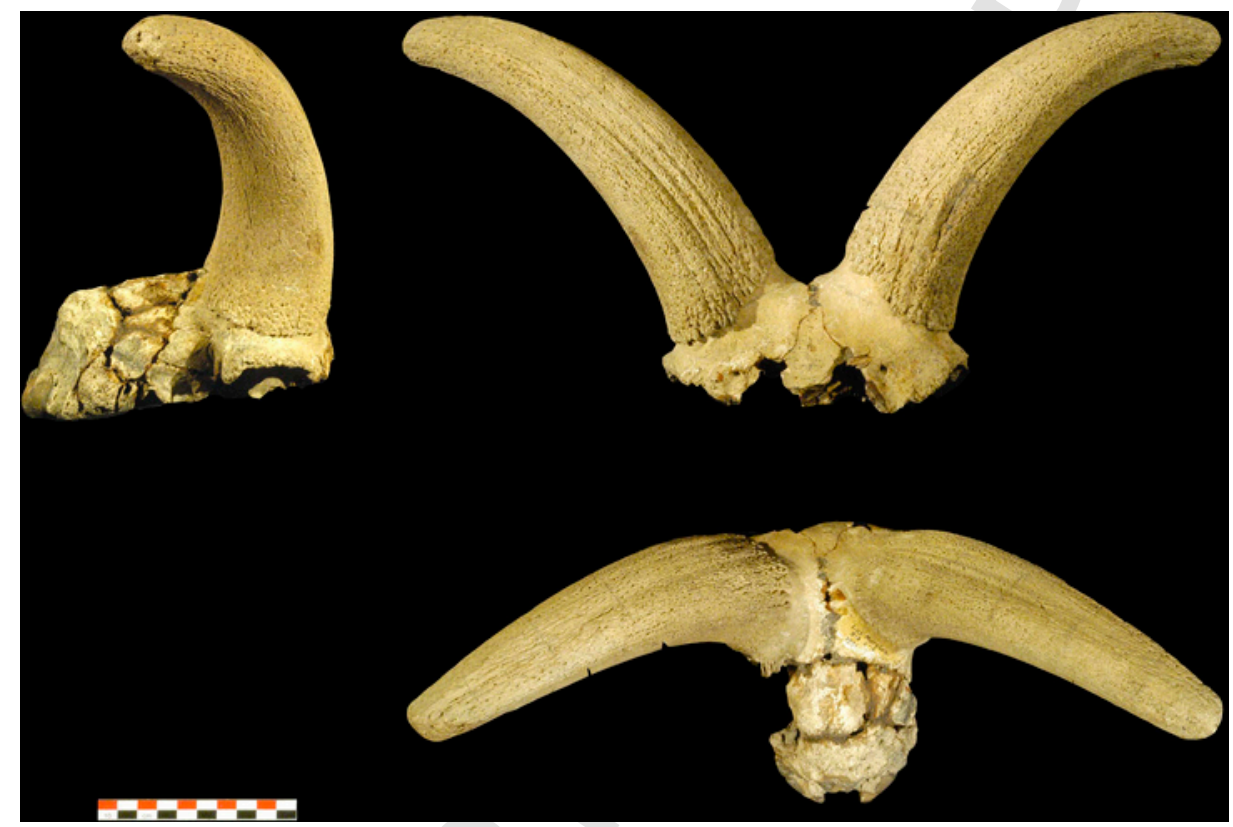

Fig. 5. Skull of Capra caucasica from Soulabé (LP, Ariège) (photo P. Jugie).Crâne de Capra caucasica from Soulabé (LP, Ariège) (photo P. Jugie).

ronment, and gives information on biochronology and the knowledge of paleoenvironments (Eisenmann, 1980, 1981, 1984, 1988, 1991a, b, 2006a; Eisenmann and Karchoud, 1982; Eisenmann and Guérin, 1984; Eisenmann and Beckouche, 1986; Dive and Eisenmann, 1991; Guérin et al., 2004; Bignon et al., 2005; Bignon and Eisenmann, 2006; Guadelli, 2013; Cucchi et al., 2017; Uzunidis-Boutillier, 2017). Furthermore, several paleogenetic studies have provided new indications on the origin and the phylogeny of Equidae or have confirmed former hypotheses, such as the date of the transition between Caballines in the broad (E. mosbachensis) and strict sense of the term (E. caballus) (Eisenmann, 2006b; Orlando et al., 2013), from MIS 6 onwards. Finally, from a more archeozoological viewpoint, several studies have focused on the structure of populations and domestication (Bogros, 1989; Bellai, 1995; Eisenmann and Arbogast, 1997; Eisenmann, 1998; Guadelli, 1998; Arbogast et al., 2002; Fernandez et al., 2006, 2017).

\subsubsection{Equus hydruntinus}

Along with "classical" studies, generally leading to biochronological results and the identification of biogeographic provinces (Eisenmann and Patou, 1980; Bonifay, 1991; Rousseau, 2008; Boulbes, 2009; Guadelli, 2011), paleogenetic research into the reconstruction of the phylogeny of E. hydruntinus (Burke et al., 2003; Orlando et al., 2006, 2009; Bennett et al., 2017) has developed over the past few years. These studies point to a proximity between Equus hemionus and E. hydruntinus, but we must admit that, for the moment, the situation is not as simple as it appears, as the paleontological and paleogenetic data do not seem to be compatible.

\subsection{Rhinocerotidae}

They are represented in France by three genera and six species (Guérin, 1980): Stephanorhinus etruscus, S. hundsheimensis, S. hemitoechus, S. kirchbergensis, Coelodonta antiquitatis and Elasmotherium sp. The incursions of the latter species into Western Eu- 


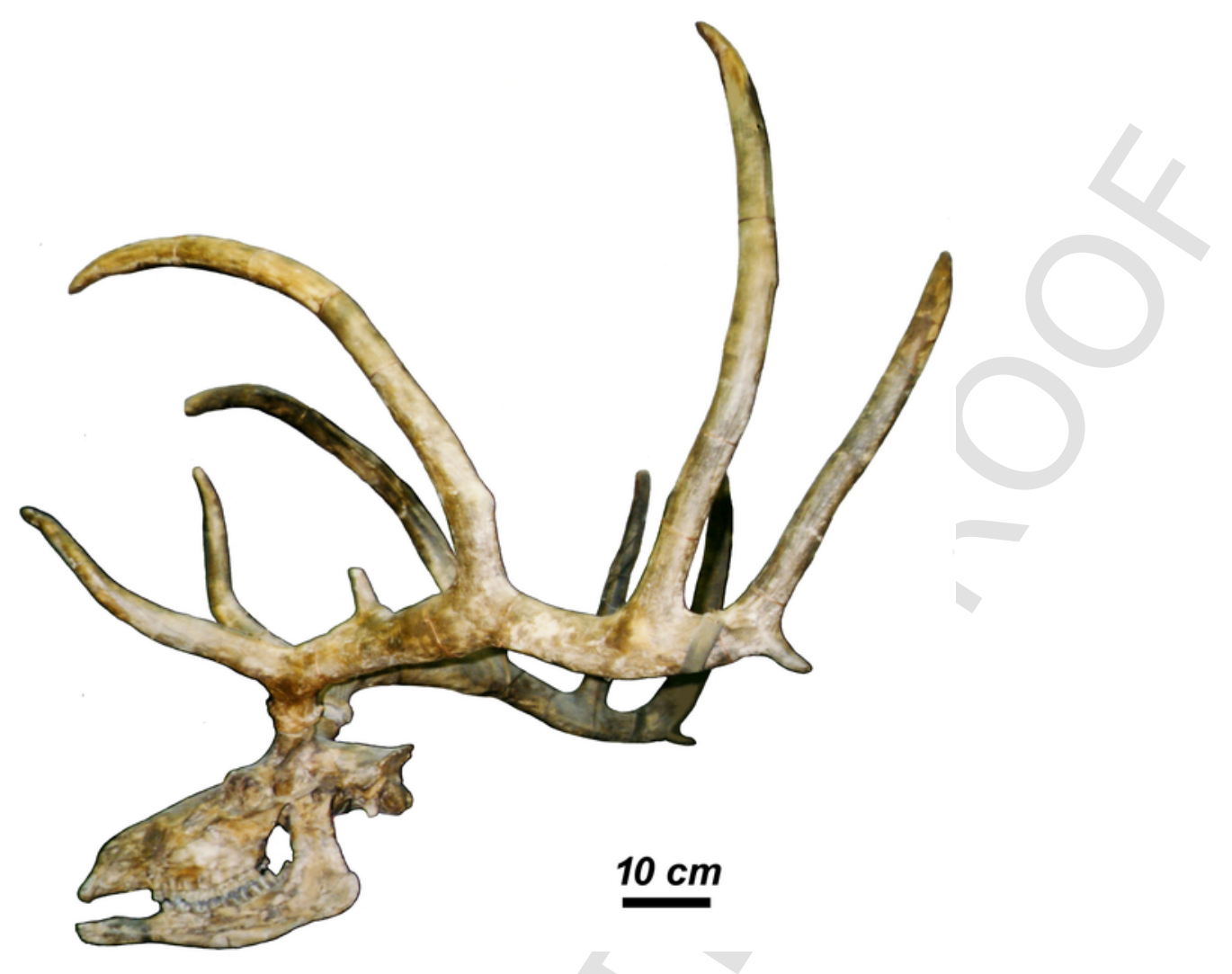

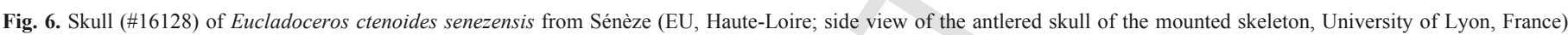

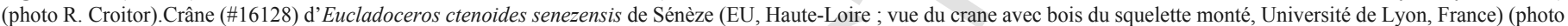
R. Croitor).

rope seem to be very rare and are only recorded in France by a single dental fragment from the collections of Ault du Mesnil from the site of Abbeville, which were destroyed during the First World War (Agache et al., 1963).

The specific determination of Stephanorhinus is often problematic, and some series are ascribed to different species depending on the authors, which limits our knowledge of the succession of the taxa and their degree of evolution, and therefore their use in biochronology. Two taxa have been described for the Plio-Pleistocene in France: S. megarhinus (Guérin, 1980) and S. jeanvireti (Guérin, 1972), which disappear before the late Early Pleistocene. Then, S. etruscus appears at Perrier-Les Étouaires (Guérin, 1972) and Saint-Vallier (Guérin, 2004) and lasts until the end of the Early Pleistocene at Senèze (Guérin, 1980; Lacombat, 2003), Chilhac (Boivin et al., 2010), Cagnes-sur-Mer (Lacombat, 2003) (attributed to Dicerorhinus etruscus brachycephalus $=S$. hundsheimensis by Guérin, 1980), Sainzelles (Lacombat, 2003) (attributed to Dicerorhinus etruscus brachycephalus $=S$. hundsheimensis by Guérin, 1980) and Bois-de-Riquet (Bourguignon et al., 2016). S. etruscus seems to have persisted in the South of France until more recently (1.3-1.1 Ma) than in the rest of Europe, apart from in the Iberian and Italian peninsulas (Pandolfi et al., 2017).

S. hundsheimensis, like S. hemitoechus, follows on from S. etruscus, and several assumptions have been made regarding its origin. Some authors suggest an Asian origin (Made, 2000), while others imply that it derives from S. etruscus (Guérin, 1980; Kahlke, 2001), or that it is completely distinct (e.g., Lacombat, 2003). In France, it is represented as early as $1.2 \mathrm{Ma}$ at Ceyssaguet, la Tour-de-Grimaldi, le Vallonnet, Saint-Prest, Abbeville, Sempigny, Durfort, and Soleil- hac and also at Vergranne (Guérin, 1980; Guérin et al., 2003; Lacombat, 2003; Schreve et al., 2007).

S. hemitoechus is regularly reported, in particular in the South of France, often in association with other rhinoceros taxa (S. kirchbergensis or Coelodonta). It is present from the beginning of the Middle Pleistocene at la Caune de l'Arago during MIS 12, then at la Baume Bonne, Terra Amata (Guérin, 1980; Lacombat, 2003), La Fage (Guérin, 1973), Orgnac III (Guérin, 1980; Lacombat, 2003), Lunel-Viel (Guérin, 1980; Lacombat, 2003; Uzunidis-Boutillier, 2017, attributed to Dicerorhinus etruscus $=$ S. etruscus by Bonifay, 1973) and Rigabe (Bonifay, 1960; Uzunidis-Boutillier, 2017). It persists until the end of the Upper Pleistocene, where it is described namely at la grotte des Enfants at Grimaldi, Monaco, dated to MIS 3 (Lacombat, 2003) (attributed to Rhinoceros mercki $=S$. kirchbergensis by Guérin, 1980). It makes several incursions into the North of France during temperate climatic periods, in particular at Cléon (MIS 9, Auguste et al., 2003), Biache-saint-Vaast (MIS 7, Auguste, 1995), Piégu (MIS 7, Auguste et al., 2005) and Caours (MIS 5, Antoine et al., 2006).

Most authors agree that $S$. kirchbergensis derives from $S$. megarhinus (Guérin, 1980; Fortelius et al., 1993; Lacombat, 2003), although others are more cautious (Billia and Petronio, 2009). It appears in France at the beginning of the Middle Pleistocene at Solheilac (MIS 17, Guérin, 1980) and disappears towards MIS 3. Like S. hemitoechus, it is mainly identified in the South of France and is contingent on wetter climates (Guérin and Patou-Mathis, 1996). It is reported notably at Vergranne (Guérin, 1983), La Fage (Guérin, 1973), Lunel-Viel (Uzunidis-Boutillier, 2017), and in the sites of Aldène, la grotte du Prince and la grotte des Enfants (Lacombat, 2003). Like S. hemitoechus, it appears episodically in the North of France, namely at Biache-saint-Vaast 


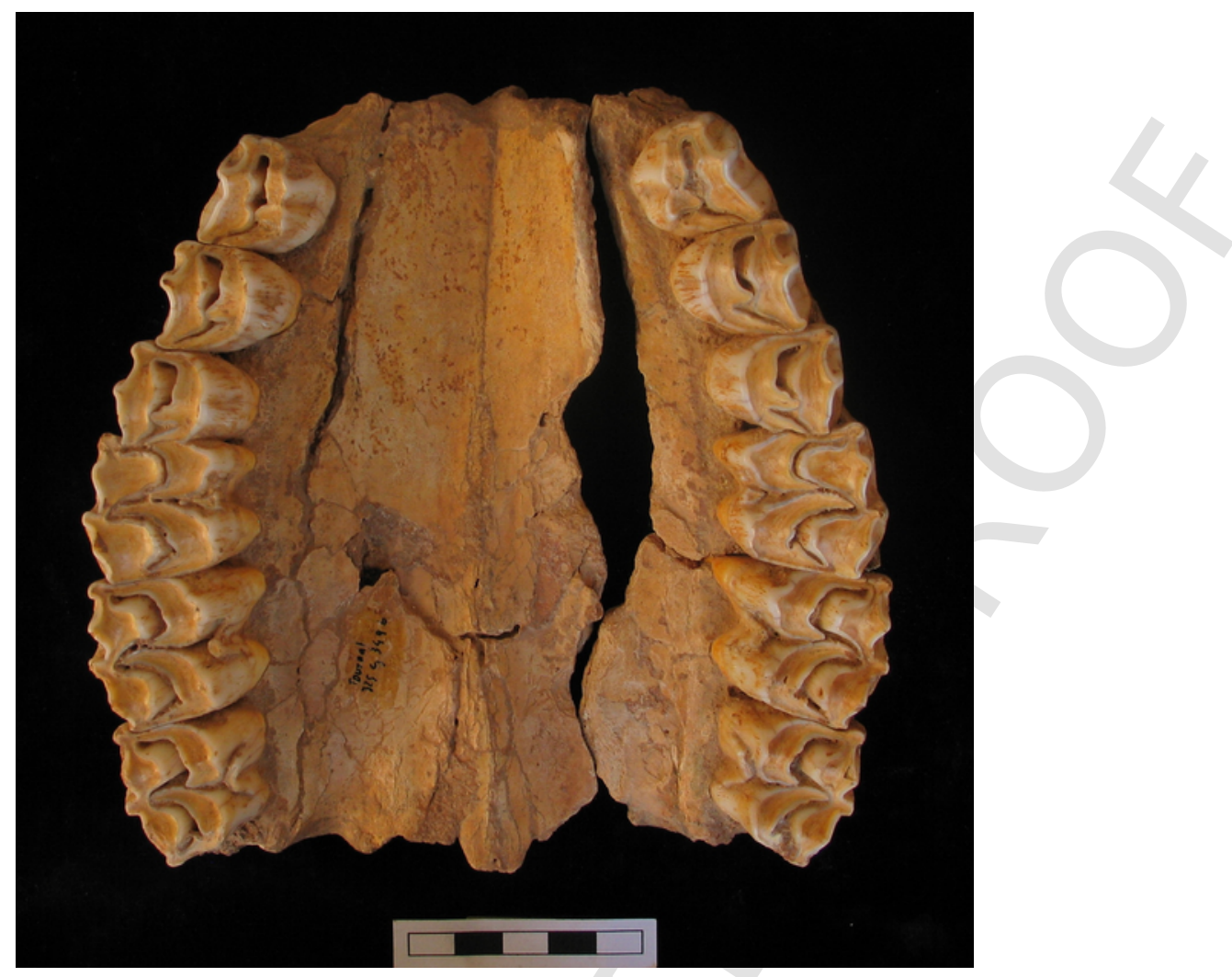

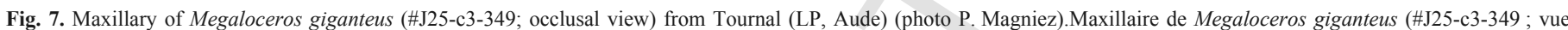
occlusale) de Tournal (LP, Aude) (photo P. Magniez).
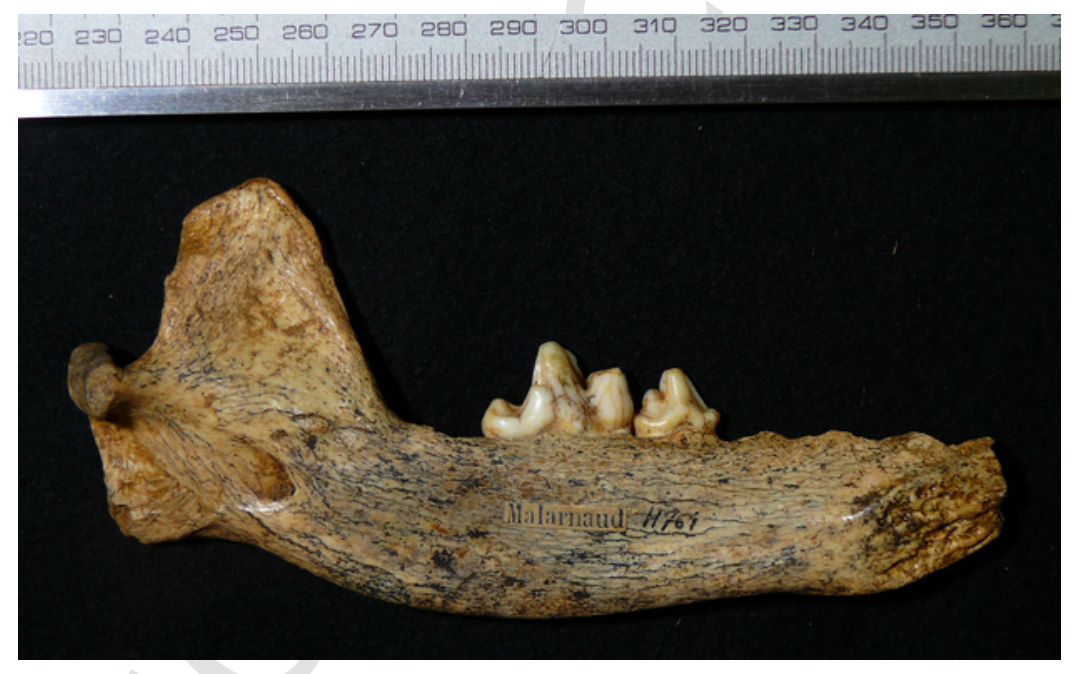

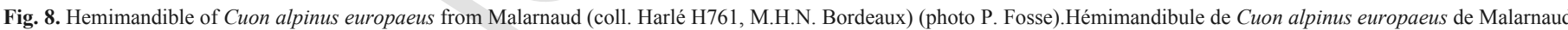
(Coll. Harlé H761, N.H.N. Bordeaux) (photo P. Fosse).

Ranville (Auguste et al., 2005), Moru and Sempigny (Guérin, 1980). In France, this taxon is practically absent during glacial periods, with a single occurrence at Pech de l'Azé II (Lacombat, 2003; Uzunidis-Boutillier, 2017).

Coelodonta is a very regular component of the faunal spectra from the middle of the Middle Pleistocene until the end of the Upper Pleistocene in the North and the South of France. The taxonomy of this taxon is also a matter of debate: the first Coelodonta found in France appears to correspond to a western expansion of the territory of C. tologoijensis (Kahlke and Lacombat, 2008). For some authors, the first French forms already appear to be much evolved and are related to $C$. antiquitatis praecursor, which reaches its final evolutionary stage during the Upper Pleistocene with $C$. antiquitatis antiquitatis (Guérin, 1980, 2010; Uzunidis-Boutillier, 2017). One of the earliest occurrences of Coelodonta in France comes from La Fage (MIS 8) and could be attributed to C. tologoijensis (Kahlke and Lacombat, 2008) but is more likely to be C. antiquitatis praecursor (Made, 2000), as is the case at the site of Igue des Rameaux (MIS 9 or 


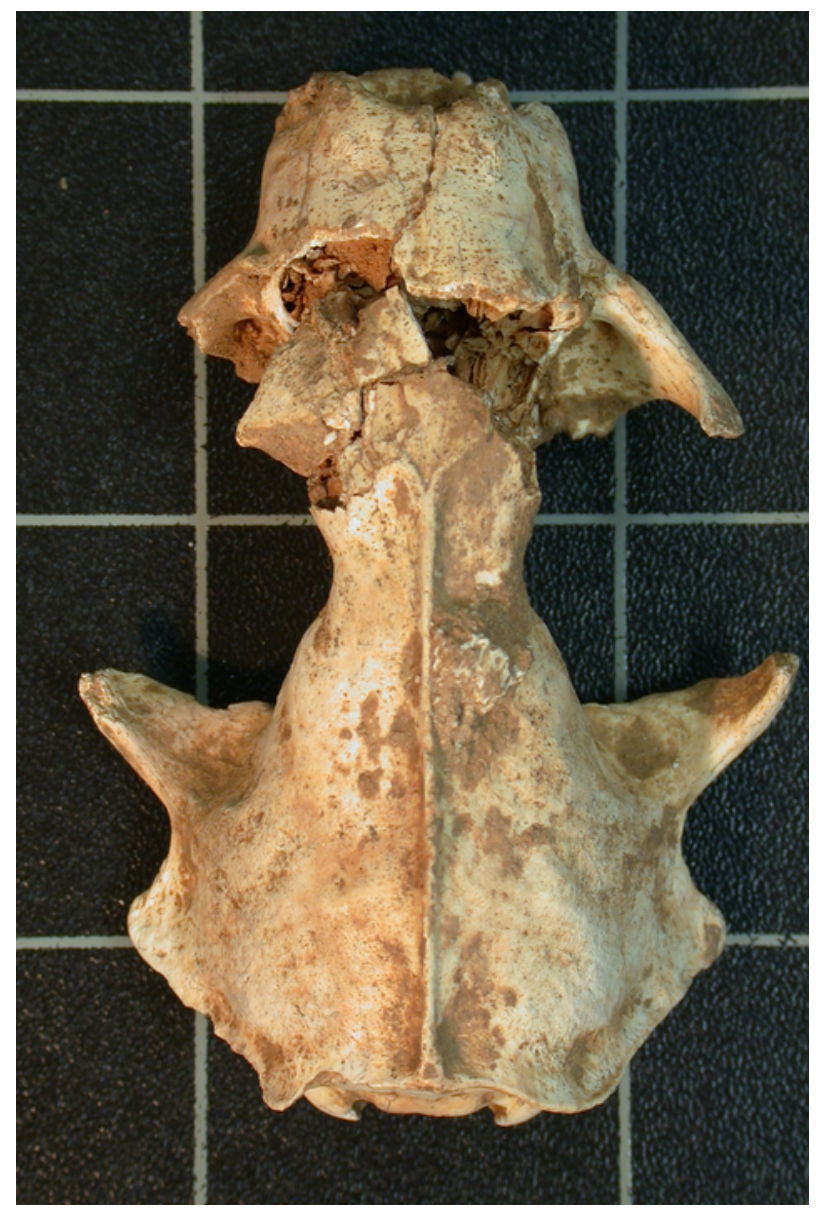

Fig. 9. Skull of Mustela (Putorius) eversmanni from Coudoulous II (level 9, MP, Lot) (scale square/white line: $3 \mathrm{~cm}$ ) (photo J.-P. Brugal).Crâne de Mustela (Putorius) eversmanni de Coudoulous II (niveau 9, MP, Lot) (échelle carré/ligne blanche $=3 \mathrm{~cm}$ ) (photo J.-P. Brugal).

7) (Rouzaud et al., 1990; Uzunidis-Boutillier, 2017). Coelodonta is present in France until MIS 2, namely at the site of Rigney (Ain), dated to around 14940 years uncal. BP (Theobald and Szymanek, 1963; Evin et al., 1978).

\section{Artiodactyles}

\subsection{Bovinae}

The Bovini tribe is represented by several genera or sub-genera (Geraads, 1992, and see Bonifay and Brugal, 1996; Brugal and Croitor, 2007), with the presence of Leptobos, Eobison, Bison and Bos in France during the Pleistocene. Some genera, such as Bubalus or Hemibos, identified in Germany or in Italy, are absent in France. The earliest are the Leptobos, which are present in several forms in many French sites during the Villafranchian, corresponding to the Gelasian and the Early Pleistocene (see taxonomic description in Crégut-Bonnoure and Guérin, 1996, chronology after Cohen and Gibbard, 2011). They have been divided into two sub-genera (Duvernois and Guérin, 1989; Duvernois, 1990, 1992) Leptobos (characterized by a double curve of the horns) with the elatus (Etouaires: Saint-Vallier, Crégut-Bonnoure and Valli, 2004) and furtivus species (Senèze: Coupet), and the sub-genus Smertiobos (horns with a simple curve) id with the etruscus species (Upper and Final Villafranchian: Senèze, Blassac-la-Girondie, Peyrolle) and bravardi (Etouaires). The relationship between this polyphyletic group, with plesiomorphic diagnostic characters (Geraads, 1992), and other European forms (for example vallisarni, stenometopon), is still debatable.

From the end of the Early Pleistocene (Epivillafranchian, 1.2-0.9 $\mathrm{Ma}$ ), archaic forms of bison are present in France, defined by the sub-genus Eobison, found for example in the sites of Riège, Sainzelle or la Sartanette (Ambert et al., 1996; Brugal and Lacombat, 2004-2005). They were rapidly supplanted by more 'modern' bison, with first of all a group comprising Bison schoetensacki, followed by the steppe bison Bison priscus. The first is present during the early and mid-Middle Pleistocene (Durfort, La Vayssiere, Vallonnet) (Brugal, 1994-1995; Brugal and Fosse, 2005), but for some authors it persists until the end of the Pleistocene (Guérin and Valli, 2000; Palacio et al., 2017). It is important to recall that sexual dimorphism is very marked in bovines and that it must be taken into serious consideration in morphometric analyses, which is not always the case. The steppe bison is the dominant form from the mid-Middle Pleistocene to the Upper Pleistocene, and is regularly found in many archaeological and paleontological sites (e.g., Auguste et al., 2005; Brugal et al., 2013; Brugal, 2016). We can cite the fossil series from the sites of Romain-la-Roche, Habarra, Jaurens or Arquet (Guérin and Valli, 2000; Prat et al., 2003; Vercoutere and Guérin, 2010; Gamberi Almendra de Carvalho et al., 2011), with abundant remains; for example, nearly 130 individuals, of both sexes, adults and juveniles (1- and 2-year-old), were found in the Arquet sinkhole dated to MIS 3 (Brugal, n.d.) The last bison in France date from the Tardiglacial and the question of a former coexistence with a form of Bison bonasus has recently been raised (Massilani et al., 2016; Grange et al., 2018). The presence of a chronological and ecological polymorphism in western European populations obstructs our perfect understanding of the taxonomy of the fossil assemblages, as well as of evolutionary mechanisms. We observe important variations in body size during the course of time (Magniez et al., 2017), and three chrono-subspecies have been identified (Brugal, 1999) at a European scale: priscus, mediator and minor, which will nonetheless require enhanced definition in the future.

The aurochs is regularly present during the Middle and Upper Pleistocene in France (and during the Holocene, Brugal, 1983), but is less frequent than the bison, and increases during temperate stages. Among the sites with abundant fossils, we can cite those from the second half of the Middle Pleistocene: Lunel-Viel in the South of France (Brugal, 1985) and Biache-Saint-Vaast in the northwest (Auguste, 2009). Variations in body size among populations in Western Europe are observed in relation with climatic phases and seem to conform to Bergmann's rule. The Pleistocene form (Bos primigenius trochoceros) is larger than the Holocene aurochs (B. p. primigenius).

\subsection{Caprinae, Antilopinae and Rupicaprinae}

Three Bovidae subfamilies are part of the Pleistocene guild of herbivores in France. These are Caprinae, Antilopinae and Rupicaprinae. In addition to a first overview (Crégut-Bonnoure and Guérin, 1996), several studies and revisions over the past thirty years have focused on their anatomic characteristics and their chronological distribution (Delpech, 1983; Crégut-Bonnoure, 1984, 1987, 1992a, 1992b 2002, 2006, 2007, 2009; Duvernois and Guérin, 1989). New species have been identified and some of the better represented taxa in natural and archaeological sites are important biochronological markers.

These three subfamilies are recorded during the Early Pleistocene, during the course of which nine genera and ten species have been identified. Caprinae are represented by Pliotragus ardeus, Gallogoral meneghinii, Megalovis latifrons, Praeovibos sp., Soergelia sp., Hemi- 

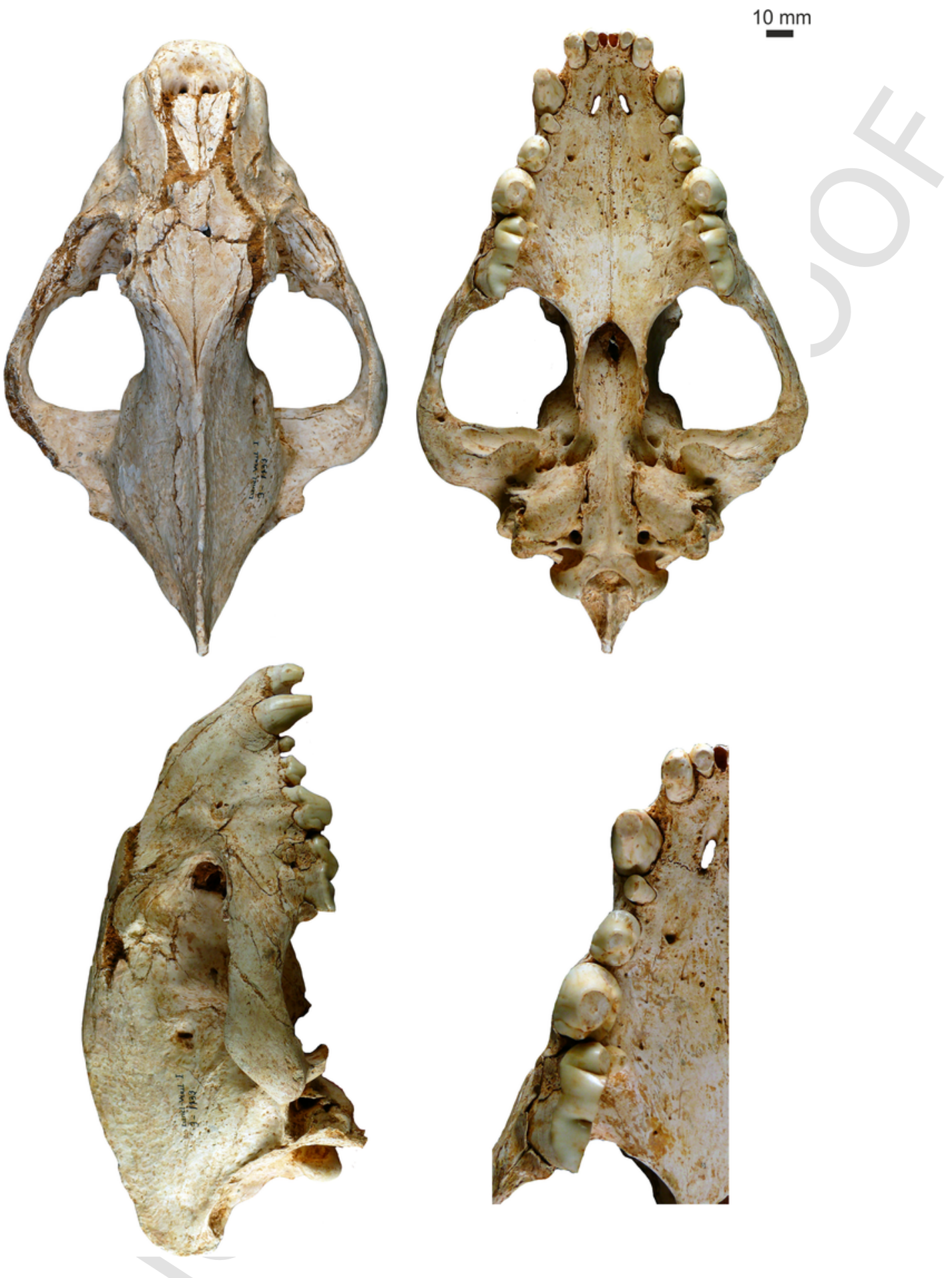

Fig. 10. Skull of Crocuta spelaea/crocuta intermedia from Lunel-Viel I (1.9\#1133; MP, Hérault) (photo P. Fosse, Plate par J.B. Fourvel).Crâne de Crocuta spelaea/crocuta intermedia de Lunel-Viel I (MP ; Hérault ; c.9\#1133) (photo P. Fosse, figure montée par J.B. Fourvel).

tragus orientalis; Antilopinae by Gazella borbonica, Gazella sp., Gazellospira torticornis; Rupicaprinae by Procamptoceras brivatense. These taxa are currently present in 14 sites (Duvernois and Guérin, 1989; Crégut-Bonnoure, 2002, 2006; Crégut-Bonnoure and Valli, 2004; Lacombat, 2004-2005): Roccaneyra, Pardines, Chagny, Montoussé 5, La Rochelambert, Saint-Vidal, Cornillet, Vals-Le-Crozas, Saint-Vallier, Le Coupet, Chilhac I and II, Senèze, Malbattu, Le Vallonnet. Although Ovis occurs at Senèze, this material be more recent as it presents different fossilization (Crégut-Bonnoure, 1992b).

Among these taxa, three have been identified over the past few years in the Vallonnet site (Michel et al., 2017). These are Praeovibos sp., probably $P$. mediterraneus, which is identified at the same time in Greece, Italy and Spain (Crégut-Bonnoure, 2002, 2006). Hemitragus is also documented at the same site $(H$. orientalis, Crégut-Bonnoure and Spassov, 2002). The Caprine interpreted as Ammotragus (A. eu- 

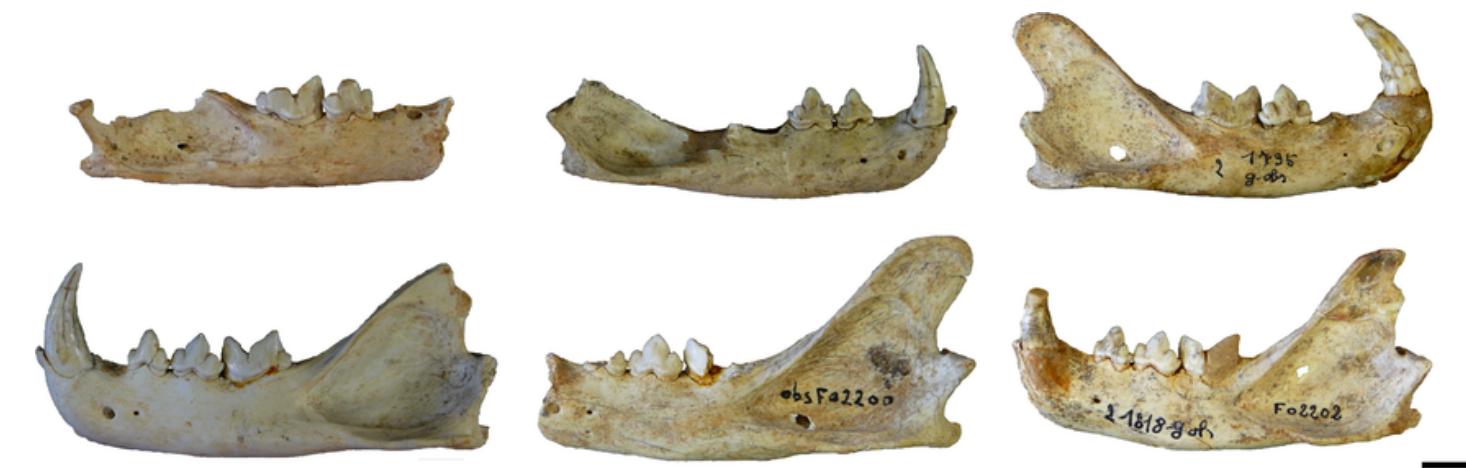

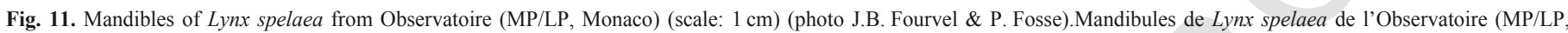
Monaco) (photo J.B. Fourvel \& P. Fosse).

ropaeus, Moullé et al., 2004) corresponds to mixed material from H. orientalis and Soergelia (Crégut-Bonnoure and Dimitijevič, 2006). Capra rozeti from Malbattu (end of the Early Pleistocene) is also attributable to Soergelia (Crégut-Bonnoure, 2002, 2006).

The Middle Pleistocene is characterized by the appearance of an association of Bovidae, comprising several species from cold and open environments, depending on climatic fluctuations. Currently, seven genera and ten species have been identified. Caprinae dominate with seven species: Praeovibos priscus, S. elisabethae, H. orientalis, H. bonali, H. cedrensis, Capra ibex, O. ammon antiqua. Antilopinae are represented by a single species: Saiga tatarica, and Rupicaprinae by two species: Rupicapra rupicapra and $R$. pyrenaica.

$P$. priscus is well known in Western Europe (Germany, Poland, England etc., Crégut-Bonnoure, 1984, 2002, 2006), but has only been identified up until now in France at la Caune de l'Arago (Crégut and Guérin, 1979; Crégut, 1980) where its morphometric characteristics have given rise to the sub-specific distinction delumleyi (Crégut-Bonnoure, 2002). At l'Igue de Saint-Sol-Belcastel, the material initially attributed to this musk ox is now ascribed to $S$. elisabethae (Philippe et al., 1980; Crégut-Bonnoure, 2002).

Among the Caprinae, H. bonali is widespread in Western Europe and in particular in France (Bonifay, 1974-1975; Crégut-Bonnoure, 1988, 2008; Crégut-Bonnoure, 2002, 2006). The hind cannon bone from Soleilhac-farm, dating from the beginning of the Middle Pleistocene, raises the question of the persistence of H. orientalis (Crégut-Bonnoure, 2006; Moullé et al., 2006b; Fernandez and Crégut-Bonnoure, 2007). H. cedrensis is the descendant of H. bonali. It is present in the southeast of France at the end of the Middle Pleistocene (end of MIS 7, beginning of MIS 6): Cimay, Les Cèdres, Rigabe, Bau de l'Aubesier (Fernandez, 2006; Crégut-Bonnoure et al., 2010), but also during the same period at Coudoulous I in the southwest, where it is particularly abundant (Fernandez, à par.) $\mathrm{A} \mathrm{P} / 3$ attributed to $H$. aff. cedrensis was identified in Spain at Bolomor (Level IV), at the end of MIS 6 (Rivals and Blasco, 2008).

C. ibex appears in Western Europe during MIS 7, and in France the oldest sites with this species are Lazaret (Gagnière, 1955), Rigabe (Crégut-Bonnoure, 1989) and Le Coustal (Crégut-Bonnoure, 2002). The only Ovis present is O. ammon antiqua, identified at Pont-du-Château. It was also identified at Camp-de-Peyre (Delpech et al., 1978) and la Caune de l'Arago (Crégut, 1979). The latter site contains the highest concentration of remains of this species in Western Europe (Moigne et al., 2006). The migration of the Saiga antelope to Western Europe is well documented (Delpech, 1983, 1988; Crégut-Bonnoure, 1992a). It first colonized the southwest of France during MIS 6 (Combe-Grenal, Abri-Suard). The Rupicapra genus is present from the beginning of the Middle Pleistocene onwards in Eastern $\mathrm{Eu}-$ rope (Fernandez and Crégut-Bonnoure, 2007; Sirakov et al., 2010), and perhaps as early as the Early Pleistocene (Crégut-Bonnoure, 2006); it appears in France during MIS 12 (Caune de l'Arago) (Crégut, 1979; Moigne et al., 2006; Rivals, 2006). The Pyrenean chamois R. pyrenaica is clearly differentiated during MIS 7 at La Niche (Crégut-Bonnoure et al., 2011) and Cap de Bielle (Clot and Marsan, 1986) (R. pyrenaica occitania), whereas (Masini and Lovari, 1988) attribute this latter taxon to $R$. cf. pyrenaica. In the southeast, from the end of the Middle Pleistocene, at Les Cèdres Cave (Crégut-Bonnoure, 1992a, b, 1995) and the large rockshelter of Bau de l'Aubesier (Fernandez, 2001, 2006), the Alpine group appears with $R$. rupicapra (Crégut-Bonnoure and Fernandez, 2004). The differentiation of this species could have occurred during an interglacial or an interstadial in Eastern Europe or in Asia Minor (Lovari and Scala, 1980; Pérez et al., 2002).

During the Upper Pleistocene, the number of small bovids decreases with five represented genera and eight species. Caprinae are represented by Ovibos pallantis, H. cedrensis, C. ibex, C. caucasica and C.pyrenaica, and Antilopinae and Rupicaprinae by the same genera and species as during the Middle Pleistocene. Ovibos is the only Upper Pleistocene Ovibovine. It is present in the northern and south-western plains (Crégut-Bonnoure, 1984, 2002). Its presence in the southeast, at Les Cèdres, has been invalidated (Crégut-Bonnoure, 1995). Among the Caprinae, H. cedrensis persists in some areas at the very beginning of the Upper Pleistocene (MIS 5e): Saint-Marcel d'Ardèche (Crégut-Bonnoure, 1989), Caune de l'Arago (Rivals, 2004, 2006), whereas it is absent from all the Upper Pleistocene levels of Coudoulous I (Fernandez, . A morphometric analysis based on 115 European sites and more than 5500 teeth brought to light an East-West and North-South gradient in the evolution of the size of the teeth of certain forms of the genus Capra (Crégut-Bonnoure and Fernandez, 2018). In France, C. ibex is observed in the southeast as early as MIS 5e: Grand Abri aux Puces (Slimak et al., 2010). From MIS 4 onwards, the species occupies practically all the mountainous zones of the South of France. The populations on either side of the Rhône River underwent different morphological developments. In the western part, the cebennarum subspecies emerges (Crégut-Bonnoure, 2002, 2006). The transformation of the dentition of the ibex east of the river is linked to a geographic isolate (Crégut-Bonnoure, 1992d, 2002, 2006). An MIS 5 morphotype is identified on either side of the Rhone, such as C. caucasica praepyrenaica (Baume Moula Guercy, Mousterian levels of Adaouste, layer IV of Bau de l'Aubesier) (Defleur et al., 2001; Crégut-Bonnoure, 2002; Fernandez, 2006). This taxon is also present during MIS 4 in the Pyrenees (ex. Malarnaud, Soulabé, Fig. 5) and the Massif Central. The transformation of the morphology of the horn cores $\bar{\equiv}$ towards 


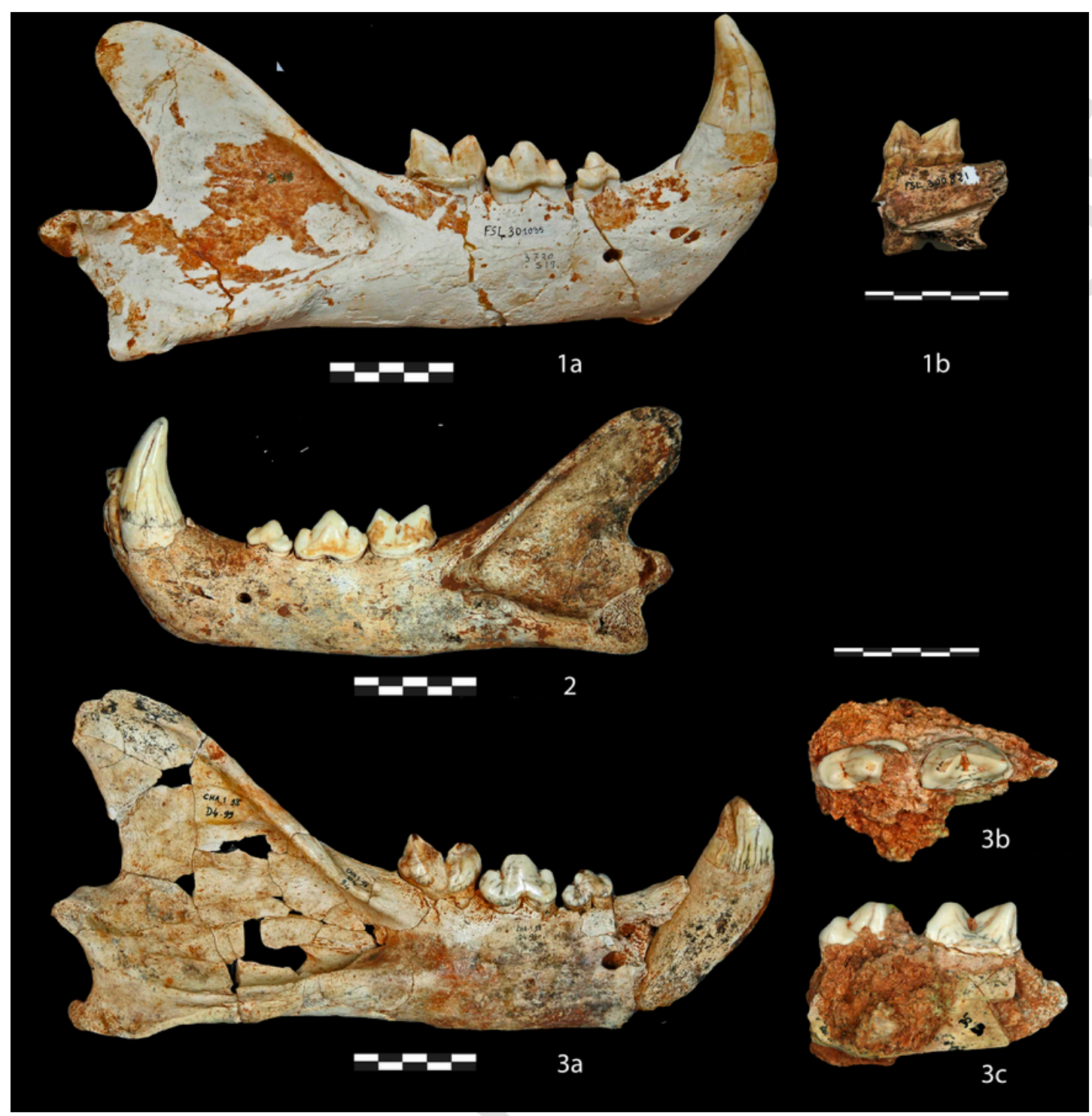

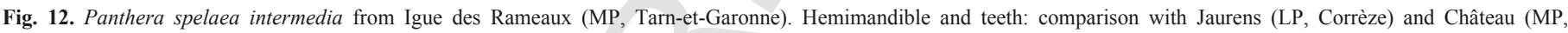

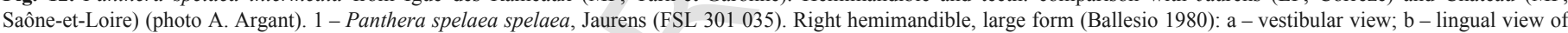

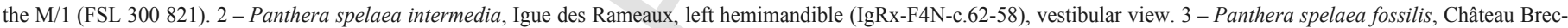

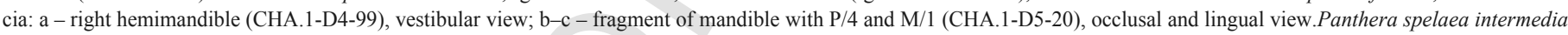

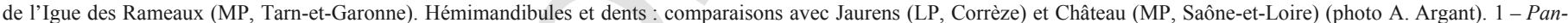

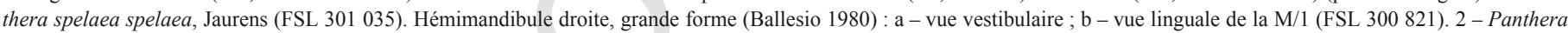

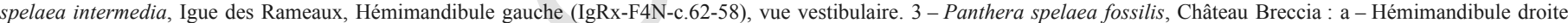
(CHA.1-D4-99), vue vestibulaire ; b-c - fragment de mandibule avec P/4 et M/1 (CHA.1-D5-20), vues occlusale et linguale.

a morphotype identifying the Pyrenean ibex is observable (speciation process). However, genetic analyses on current species do not validate this scenario as they highlight the proximity of the Alpine and Pyrenean ibex (Ureña et al., penetic drift from the Alpine ibex is conceivable: morphological similarities with the Caucasian ibex would be simple analogies (Magniez, 2009). This scenario is not entirely satisfactory as certain anatomical characters are associated with other evolved characters (Crégut-Bonnoure, 2009). C. pyrenaica, which follows on from the preceding species, is considered to be confined to the Pyrenean massif, but its habitat range extended sporadically to the Massif Central and its fringes during MIS 2: le Marronnier, Baume d'Oullins, Abri (=rockshelter) Dumas, Abri du Colombier, La Salpêtrière, Grotte Chabot, La Crouzade, Grau de Padern, Gazel, Belvis, Bruniquel (Crégut-Bonnoure, 2002).
The Saiga antelope is abundant throughout the southwest of France (Delpech, 1983; Dujardin and Tymula, 2005; Castel and Madelaine, 2006; Castel et al., 2010), with the presence of several whole skeletons at Quéroy (Tournepiche, 1982). It is also recorded in the Languedoc plain and on the edge of the Rhône River (Crégut-Bonnoure and Gagnière, 1981), as well as in the plains of the Lower Rhône Valley (Abri Cornille, Chinchon I) (Crégut-Bonnoure and Paccard, 1997). Finally, the chamois and the Pyrenean chamois rapidly colonized the whole southeast of France and the Pyrenean zone respectively. The specific status of Rupicapra is mostly uncertain for the Massif Central, but both taxa must have been present in this region, as shown by the existence of $R$. pyrenaica to the south of this massif, at Marie Cave (Crochet et al., 2007). 
Table 2

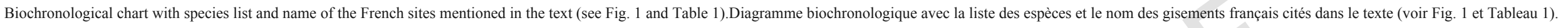

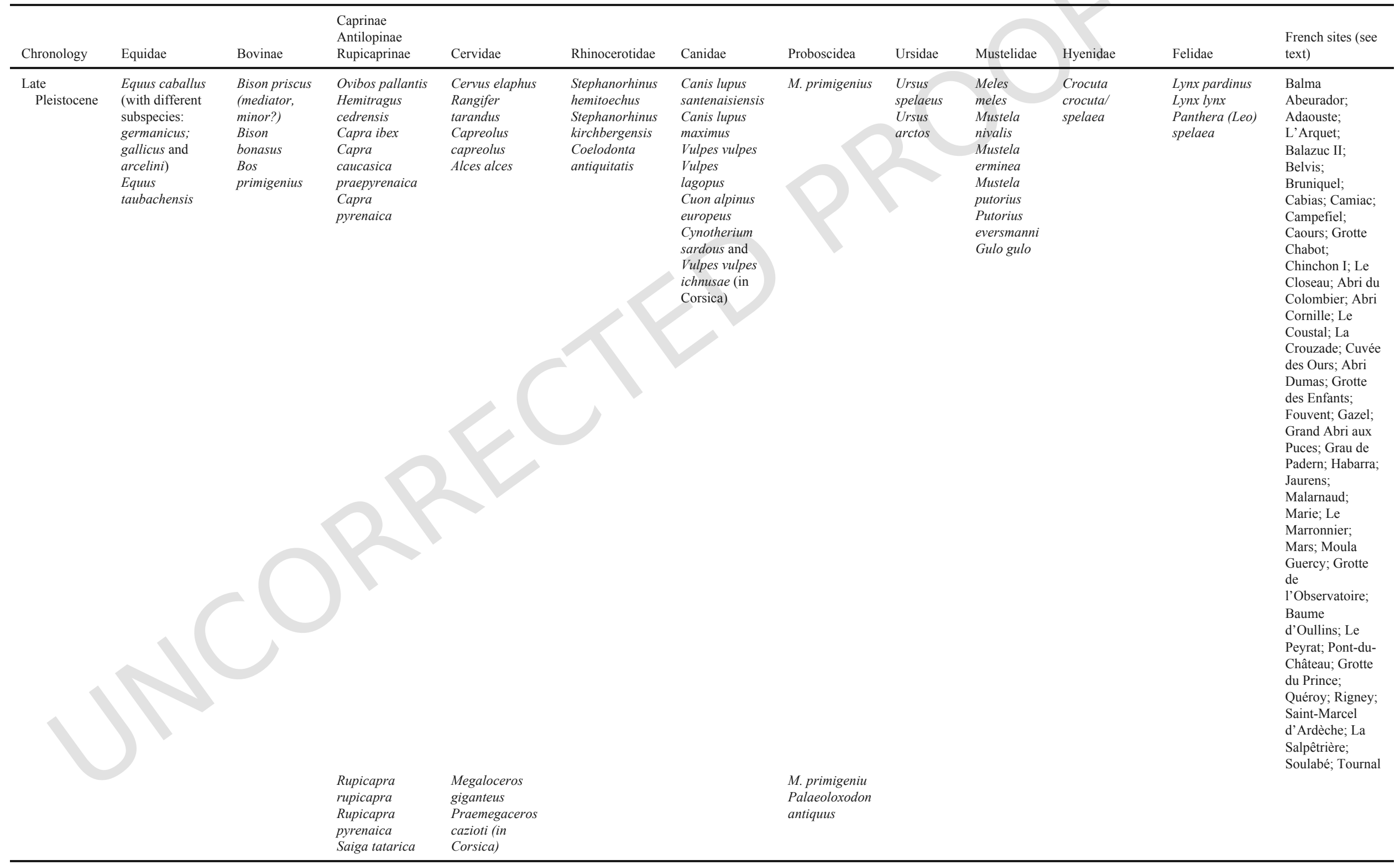


Table 2 (Continued)(Diagramme biochronologique avec la liste des espèces et le nom des gisements français cités dans le texte (voir Fig. 1 et Tableau 1).)

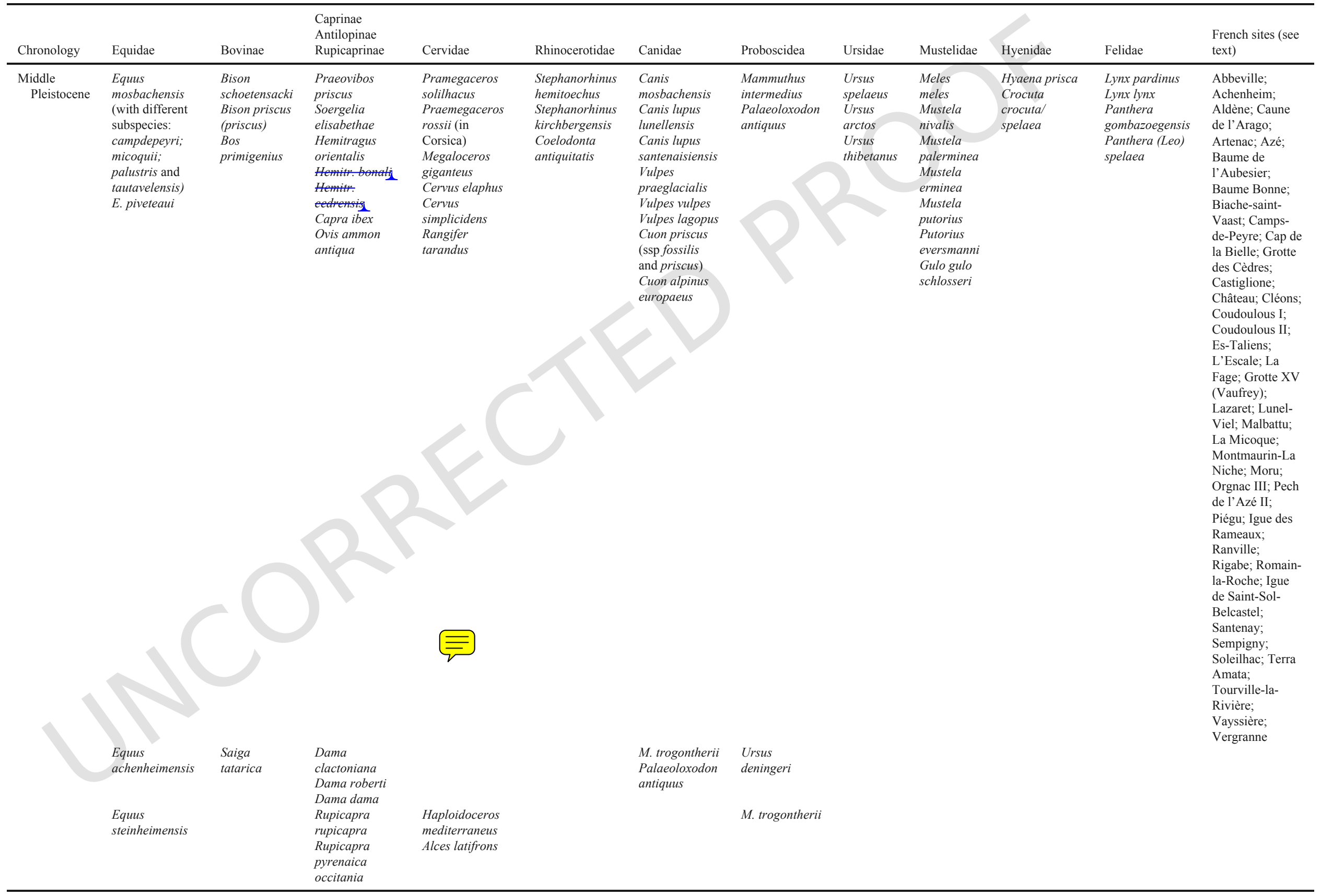


Table 2 (Continued)(Diagramme biochronologique avec la liste des espèces et le nom des gisements français cités dans le texte (voir Fig. 1 et Tableau 1).)

\begin{tabular}{|c|c|c|c|c|c|c|c|c|c|c|c|c|}
\hline Chronology & Equidae & Bovinae & $\begin{array}{l}\text { Caprinae } \\
\text { Antilopinae } \\
\text { Rupicaprinae }\end{array}$ & Cervidae & Rhinocerotidae & Canidae & Proboscidea & Ursidae & Mustelidae & Hyenidae & Felidae & $\begin{array}{l}\text { French sites } \\
\text { (see text) }\end{array}$ \\
\hline $\begin{array}{l}\text { Lower } \\
\text { Pleistocene }\end{array}$ & Equиs stenonis & $\begin{array}{l}\begin{array}{l}\text { Leptobos } \\
\text { elatus; }\end{array} \\
\text { Leptobos } \\
\text { furtivus } \\
\text { Smertiobos } \\
\text { etruscus; } \\
\text { Smertiobos } \\
\text { bravardi } \\
\text { Eobison sp. } \\
\text { Bison } \\
\text { schoetensacki }\end{array}$ & $\begin{array}{l}\text { Pliotragus } \\
\text { ardeus } \\
\text { Gallogoral } \\
\text { meneghinii } \\
\text { Megalovis } \\
\text { latifrons } \\
\text { Praeovibos } \\
\text { mediterraneus } \\
\text { Soergelia } \\
\text { elisabethae } \\
\text { Gazella } \\
\text { borbonica } \\
\text { Gazellospira } \\
\text { torticornis } \\
\text { Procamptoceras } \\
\text { brivatense } \\
\text { Ovis ammon } \\
\text { antiqua } \\
\text { Hemitragus cf. } \\
\text { orientalis }\end{array}$ & $\begin{array}{l}\text { Eucladoceros ctenoides } \\
\text { [with different } \\
\text { subspecies: vireti, } \\
\text { senezensis }=\text { falconeri?, } \\
\text { tetraceros and ssp. (cf. } \\
\text { ctenoides?)] } \\
\text { Eucladoceros dicranios } \\
\text { Praemegaceros } \\
\text { obscurus; } \\
\text { Praemegaceros sp. (cf. } \\
\text { verticornis?) } \\
\text { Arvernoceros giulii } \\
\text { Croizetoceros ramosus } \\
\text { Metacervocerus } \\
\text { rhenanus } \\
\text { Dama vallonnetensis; } \\
\text { Dama sp. }\end{array}$ & $\begin{array}{l}\text { Stephanorhinus } \\
\text { hundsheimensis } \\
\text { Stephanorhinus } \\
\text { etruscus }\end{array}$ & $\begin{array}{l}\text { Canis } \\
\text { etruscus } \\
\text { Canis } \\
\text { arnensis } \\
\text { Vulpes } \\
\text { alopecoides } \\
\text { Xenocyon } \\
\text { lycanoides }\end{array}$ & $\begin{array}{l}\text { Mammuthus } \\
\text { meridionalis } \\
\text { Anancus } \\
\text { arvernensis } \\
\text { Zygolophon } \\
\text { borsoni }\end{array}$ & $\begin{array}{l}\text { Ursus } \\
\text { etruscus } \\
\text { Ursus } \\
\text { deningeri }\end{array}$ & $\begin{array}{l}\text { Meles } \\
\text { thorali }\end{array}$ & $\begin{array}{l}\text { Pachycrocuta } \\
\text { brevirostris } \\
\text { Pachycrocuta } \\
\text { (= Pliocrocuta) } \\
\text { perrieri }\end{array}$ & $\begin{array}{l}\text { Megantereon } \\
\text { cultridens } \\
\text { Homotherium } \\
\text { crenatidens } \\
\text { Acinonyx } \\
\text { pardinensis } \\
\text { Puma } \\
\text { pardoides } \\
\text { = Panthera } \\
\text { Dinofelis sp. } \\
\text { Lynx } \\
\text { issiodorensis } \\
\text { Lynx lynx }\end{array}$ & $\begin{array}{l}\text { Les Etouaires; } \\
\text { Vialette; Saint- } \\
\text { Vallier; } \\
\text { Chilhac; Le } \\
\text { Coupet; Senèze; } \\
\text { Blassac-la- } \\
\text { Girondie; } \\
\text { Peyrolles; } \\
\text { Sainzelles; } \\
\text { Cagnes-sur- } \\
\text { Mer; } \\
\text { Roccaneyra; } \\
\text { Ceyssaguet; La } \\
\text { Sartanette; } \\
\text { Riège; Bois-de- } \\
\text { Riquet; Saint- } \\
\text { Prest; Grosse } \\
\text { Marguerite; } \\
\text { Aven des Trois } \\
\text { Pigeons; Tour- } \\
\text { de-Grimaldi; Le } \\
\text { Vallonnet; } \\
\text { Durfort; } \\
\text { Chagny; } \\
\text { Pardines; } \\
\text { Rozières }\end{array}$ \\
\hline
\end{tabular}




\subsection{Cervidae}

The French sites have yielded the richest fossil Cervidae collections, illustrating the diversity of this family. The typical Early Pleistocene forms clearly differ from the subsequent Middle Pleistocene forms populating Western Europe following faunal turnover.

After the seminal work of (Heintz, 1970), several studies of the representatives of this family during the Early Pleistocene note the difficulties surrounding the identification and phylogenetic reconstruction of fossil series. In short, large cervids are represented by the genera Eucladoceros (Croitor and Bonifay, 2001; Valli, 2004; Valli et al., 2006), Praemegaceros (Croitor and Bonifay, 2001; Guérin et al., 2003; Bourguignon et al., 2016), Arvernoceros (Croitor, 2009) and Cervalces (Heintz, 1970; Guérin et al., 2003). Eucladoceros ctenoides, with simple comb-shaped antlers, is the most abundant. Different forms, considered to be subspecies, have been described based on antler variability: E. c. vireti (Saint-Vallier), E. c. senezensis (e.g., Senèze: Fig. 6), Chilhac, a form probably synonymous with $E$. c. falconeri (Croitor, 2018), E. c. tetraceros (Peyrolles). E. ctenoides ssp. from Ceyssaguet presents antler morphology characteristic of E. c. ctenoides from the Upper Valdarno in Italy. E. dicranios was reported in the diluvian sands of Riège under the name of Cervus martialis (Gervais, 1859). Rare Praemegaceros obscurus remains were discovered in the Final Villafranchian of Ceyssaguet (Croitor and Bonifay, 2001). Praemegaceros solilhacus is described as being associated to the beginning of the Middle Pleistocene at Soleilhac and L'Escale (Bonifay, 1981). Praemegaceros verticornis is less frequent in France: the remains discovered at Bois-de-Riquet (Praemegaceros sp., Bourguignon et al., 2016), may be attributed to it and it is probable that the remains of a large deer from the Paris basin described by (Belgrand, 1883) as "Cervus belgrandi" may also be ascribed to this species (Croitor, 2018). Arvernoceros giulii is a large-sized form of deer from the end of the Early Pleistocene from Rosières. It is very likely that the large deer remains from Saint-Prest and le Vallonnet represent the same form (Croitor, 2018). The Praemegaceros genus persists throughout the first half of the Middle Pleistocene on the European continent (Croitor, 2006(e). In Corsica, an isolated insular lineage of Praemegaceros is represented by two species: $P$. rossii during the Middle Pleistocene at Castiglione and P. cazioti from the site of La Coscia, a dwarf form existing until the Pleistocene/Holocene transition (Pereira, 2001; Croitor et al., 2006; Croitor, 2018).

The latest work on small and medium-sized cervids from this period in France seems to recognize three genera: Croizetoceros with a single species C. ramosus (Heintz, 1970; Valli, 2004), Metacervocerus and Dama (Croitor, 2006 (A). M. rhenanus remains are relatively abundant in Early Pleistocene sites [e.g., Saint-Vallier, Senèze, Chilhac, Ceyssaguet (Heintz, 1970; Croitor and Bonifay, 2001)]. Dama is rarer and is described at le Vallonnet (D. vallonnetensis, type locality), Dama sp. at Ceyssaguet (Croitor and Bonifay, 2001) and recently at Senèze on the basis of the analysis of the bony labyrinth of the inner ear (Mennecart et al., 2017).

The characteristic Middle and Upper Pleistocene genera are Megaloceros, Cervus, Dama, Haploidoceros, Alces, Rangifer and Capreolus. The giant deer M. giganteus (Fig. 7) is recognized in France from the end of the Middle Pleistocene to the end of the Upper Pleistocene (Magniez, 2010). The red deer Cervus elaphus arrives in Western Europe at the Early/Middle Pleistocene transition. In France, the sites of Soleilhac and la Caune de l'Arago (levels earlier than $500 \mathrm{ky}$ ) yield a form with no differentiated crown at the apex of the antlers: Cervus e. acoronatus (Magniez et al., 2013). From 500 ky onwards, crowns are more frequent (Cervus e. elaphus). Other forms are identified: for example, C. simplicidens (Guadelli, 1996) at Combe-Grenal; or, for exceptionally large red deer remains and antlers with basal beams on the same plane which could potentially be attributed to $C$. canadensis, as recently proposed in Moldova (Croitor and Obada, 2017). This taxon may have spread to Western Europe during a cold Upper Pleistocene phase (Croitor and Obada, 2017; Croitor, 2018). A larger fallow deer than the Early Pleistocene form, similar to Dama clactoniana, is reported at the Middle Pleistocene sites of Orgnac III (Aouraghe, 1990), Caune de l'Arago (Moigne et al., 2006) and La Fage (Bouchud, 1972). These determinations would invalidate the occurrence of Cervus elaphoides (Lister, 1990). The remains of "Dama polignacus" from Soleilhac belong to a juvenile Dama clactoniana specimen (ferding to another study (Magniez et al., 2013), the fallow deer remains from Soleilhac and la Caune de l'Arago correspond to Dama roberti. From the end of the Middle Pleistocene onwards, the fallow deer series can be attributed to Dama dama. The revision of the Cervidae from the sites of Lunel-Viel and Igue des Rameaux, from the second half of the Middle Pleistocene, led to the description of Haploidoceros mediterraneus (Croitor et al., 2008), recently found in Spain at the beginning of MIS 5 (Sanz et al., 2014). The genus Alces is very rare during the Middle Pleistocene. Remains belonging to A. latifrons were brought to light at Achenheim. The current form of the elk Alces alces was mainly identified in sites from the end of the Pleistocene and the Holocene (Chaix and Desse, 1981; Delpech, 1983). The reindeer, Rangifer tarandus, is represented in France from the Middle Pleistocene onwards [e.g., la Caune de l'Arago (Crégut, 1980; Magniez et al., 2013)]. It is relatively rare during the second half of the Middle Pleistocene and becomes very abundant during the Upper Pleistocene, when it is the main target of Middle and Upper Palaeolithic hunters. The roe deer, Capreolus capreolus, is rare in French Middle Pleistocene sites and is better represented during the Upper Pleistocene, but often in small numbers.

\section{Proboscideans}

Two families of proboscideans are presents in France. Although regularly reported in palaeontological and archaeological sites, fossil remains of Mastodontidae are rarely abundant. There are no recent studies on this group, and just a brief summary will be briefly proposed (see Guérin and Patou-Mathis, 1996). Anancus avernensis is a Tertiary form (upper Miocene), which still survives until the middle Villafranchian (Saint-Vallier) and early in the upper Villafranchian, as in Chilhac with a subspecies described.

Two lineages of Elephantidae are known during the Pleistocene, well-represented in France. The first refers to Elephas, or Paleoloxodon (sub-genus) from Africa (Beden, 1979) and Europe. P. antiquus is present in several French sites, especially during the Middle Pleistocene and continues until the very beginning of the early Pleistocene. It is the ancestor of the island forms of the Mediterranean, Eastern particular (Crete, Cyprus, etc.). The second lineage, more emblematic of Prehistory, concerns the genus Mammuthus, which in Europe shows a continuous lineage with five successive taxa: $M$. gromovi, M. meridionalis, $M$. trogontherii, $M$. intermedius and M. primigenius. Only the last four species are present in France from almost a thousand sites listed (Labe, in progress).

If the first is not formally recognized in France, M. meridionalis is known in many deposits, since that of Saint-Vallier, but also Chilhac, Senèze, Saint-Prest and Durfort, and more sites from the valley of the Saône River. A complete skeleton from Durfort is exhibited in the paleontology gallery of MNHN (Paris), site attributed to the end 
of Early Pleistocene. M. trogontherii is the typical representative of the Middle Pleistocene (sites Abbeville, Saint-Acheul), and probably ancestor of $M$. intermedius. This taxon have been recently redefined from the material of La Fage I and Romain-la-Roche (Labe and Guèrin, 2005; Paupe et al., 2010) dated to the end of Middle Pleistocene. It is also recognized at Coudoulous II (level 9, Uzunidis and Brugal, 2018; Labe and Brugal, in press). This form is the direct ancestor of Mammuthus primigenius, common in the Upper Pleistocene site in all the French regions and regularly depicted in the rock and portable paleolithic art.

\section{Caniformia}

\subsection{Canidae}

Canidae are relatively omnipresent in fossiliferous sites and a lot of work has been carried out on them over the past four decades (e.g., review in Boudadi-Maligne, 2010). Several taxa occur regularly during the Pleistocene: Canis etruscus, C. arnensis, Vulpes alopecoides and Xenocyon lycanoides during the course of the Early Pleistocene, as shown by the sites of Saint-Vallier (Argant, 2004), le (Moullé et al., 2006a) or Ceyssaguet (Argant, 2004; Tsoukala and Bonifay, 2004; Brugal and Boudadi-Maligne, 2011). Canis mosbachensis, C.lupus, Vulpes praeglacialis, V.vulpes, V.lagopus (=Alopex lagopus), Cuon priscus and Cuon alpinus europaeus occur throughout the country during the Middle Pleistocene. In Corsica, Canidae also occur during the Upper Pleistocene, mainly represented by Cynotherium sardous (Salotti et al., 2000) and more discreetly by a small fox $V$. vulpes ichnusae (Pereira et al., 2005). The canid species are of considerable biochronological interest and contribute in defining palaeoenvironments. The Canis genus has been continuously present in Western Europe since its appearance, more than three million years ago, until the present day. On account of this constancy, it is an excellent marker of the variation of palaeoenvironments, in spite of its ubiquitous character. However, the phylogeny of the Canis genus is still widely debated (Garrido and Arribas, 2008; Boudadi-Maligne, 2010; Brugal and Boudadi-Maligne, 2011). New fossil species continue to be described for the Early and Middle Pleistocene, complicating our knowledge of this genus and its evolution. This blurred vision can be explained by the absence of quantification of individual intra-specific variations, and by the fact that spatially and temporally dispersal data are taken into consideration in phylogenies.

The wolf lineage is an excellent biochronological tool. From the end of the early Middle Pleistocene (MIS 10) and during the Upper Pleistocene (until MIS 3), the size of individuals increased continuously, leading to the description of three chrono-subspecies: C. lupus lunellensis [Lunel-Viel, (Bonifay, 1971), C. lupus santenaisiensis (Santenay, Argant, 1991)] and C. lupus maximus (Jaurens, Boudadi-Maligne, 2012). This trend was brought to light at the end of the 1960 s based on the antero-posterior diameter of the lower carnassial teeth (Bonifay, 1971; Brugal, 1981; Hadjouis, 1982; Patou, 1984; Argant, 1991; Valensi, 1994). The multivariate analysis of cranial, dental and post-cranial biometric data clarified and refined this intra-specific evolution, reinforcing the biochronological contribution of canids (Boudadi-Maligne, 2010, 2012). The Cuon genus is relatively well-represented in French sites and a comprehensive study (Brugal and Boudadi-Maligne, 2011) shows the possible distinction between the different chronological forms: C. priscus with two chrono-subspecies (priscus and fossilis) during the Middle Pleistocene, followed by C. alpinus europaeus (Fig. 8) during the Upper Pleistocene (and C. a. alpinus for present-day species).

\subsection{Ursidae}

Several taxa occur in French sites: Ursus etruscus, U. deningeri, $U$. spelaeus, U. arctos, U. thibetanus. The cave bear Ursus spelaeus is a remarkable case. It is abundant in closed cave environments where the remains of dead animals are well preserved over very long periods of time (hundreds of thousands of years, and hundreds or thousands of individuals), and it provides incomparable statistical series in the domain of paleontology. When it is well studied (e.g., Prat and Thibault, 1976; Argant, 1991, 1995), it becomes an important element for biochronology (sites with at least 20 individuals) or palaeoethology (Fosse et al., 2002). According to the widely accepted evolutionary lineage, the cave bear descends from Ursus etruscus, followed by the ancestral form Ursus deningeri, which is well-represented for example at Château and Azé, then the typical form, Ursus spelaeus. In reality, the situation is clearly more complex, as shown by the existence of the subspecies U. spelaeus spelaeus, U. spelaeus ladinicus, and the appearance of Ursus eremus, Ursus ingressus (Bocherens, 2008) These two latter species do not occur in France, where only U. s. spelaeus has been identified.

Ursus arctos also stemmed from the evolution of Ursus etruscus and developed successfully up until now. The oldest currently known $U$. arctos are the mid-Middle Pleistocene specimens from Vergranne and Château. This species is omnivorous, but more carnivorous than the cave bears (Bocherens, 2008) and probably better adapted to heat, and it resisted the Tardiglacial-Holocene transition. Ursus thibetanus is also present in France, although it is not common. It occurs in France during the Middle Pleistocene, during MIS 7 for example at Coudoulous 1 (Argant, in press), and about a dozen other sites (Argant and Crégut-Bonnoure, 1996).

The OURSALP Programme brings together data on bears (fossil or subfossil U. spelaeus and U. arctos) from the Jura and the Alps. The multiplication of ${ }^{14} \mathrm{C}$-AMS dates on bears now gives us an accurate chronological framework, which is indispensable for understanding population dynamics with isotopic and paleogenetic analyses. The reasons for their disappearance are undoubtedly multiple, but the disappearance of the cave bear can mainly be attributed to climate change at the end of the last Tardiglacial. The Chartreuse Mountains, which were not covered in ice during the last glacial maximum, yielded the last known U. spelaeus, dated to $13,990 \pm 50 \mathrm{Ly}-2545$ (OxA). It comes from la Cuvée des Ours (1641 m asl) (Argant et al., 2012, 2018, 2019). This mountain range probably corresponds to a refuge zone as the dates of extinction of the cave bear in Europe seem to be earlier. The disappearance of the brown bear is unquestionably due to direct human action owing to hunting and elimination, reinforced by the anthropogenic impact on the natural environment.

\subsection{Mustelidae}

The Mustelidae family is much diversified and it is possible to identify (Crégut-Bonnoure, 1996a,-b): Gulo gulo (ssp. schlosseri and spelaeus), Mustela praenivalis, M. nivalis, M. palerminea, M. erminea, M. lutreola, M. putorius, M. eversmanni, Martes martes, Meles thorali, Meles meles, Lutra lutra. At the site of Saint-Vallier, M. thorali is present as early as 2.2-2.5 Ma (Argant, 2004) and is subsequently replaced by $M$. meles during the Middle Pleistocene.

Mustelidae are frequent in many French sites, but studies are still rare (Mallye and Guérin, 2002; Mallye, 2007). The site of Romain-la-Roche, related to MIS 6, contains M. meles, M. nivalis, M. erminea, M. putorius and probably Putorius eversmanni (Fosse and Fourvel (Fig. 9). This latter species occupies steppe-like environ- 
ments and appears during the Middle Pleistocene at La Fage, dated to MIS 8-7 (Mourer-Chauviré et al., 2003). It is still present during the final stage of MIS 6 at Coudoulous II and becomes more abundant during the Upper Pleistocene (Tournepiche, 1996: fig. 18). The wolverine also occurs at La Fage (Bourgeois and Philippe, 2017) and in about fifteen other Upper Pleistocene sites (see figure 6 in Bourgeois and Philippe, 2017), and the subspecies schlosseri is reported in the early Middle Pleistocene of l'Escale (Bonifay, 1971). The otter is not frequent and little is known about its origin. It is sometimes controversially reported during the Middle Pleistocene, but generally occurs during the Upper Pleistocene, like at Balazuc II (Argant, 2018) and le Grand Abri aux Puces (Slimak et al., 2010).

\section{Feliformia}

\subsection{Hyenidae}

This family is well-represented in France by the following species: Pachycrocuta brevirostris, Pachycrocuta (=Pliocrocuta) perrieri, Chasmaporthetes lunensis, Crocuta spelaea, Hyaena prisca. The two species of giant hyenas (P. brevirostris and P. perrieri) of the Pachycrocuta genus develop during the Early Pleistocene, and then became extinct around $600 \mathrm{ky}$ with the last representative of this genus (Turner and Anton, 1996). In France, these early forms have only yielded a few remains. P. perrieri has been identified in several Plio-Pleistocene sites in the Massif Central: e.g., Saint-Vallier (Argant, 2004), Chagny (Argant, 1991), Senèze (Bœuf, 1997) or Vialette (Lacombat et al., 2008). The giant hyena P. brevirostris (defined at Sainzelles) has only been described in six sites, including la Sartanette (Bonnet, 1980), Ceyssaguet (Tsoukala and Bonifay, 2004), la Grosse Marguerite and the Trois Pigeons sinkhole (Fourvel and Lateur, 2015) and Bois-de-Riquet (Bourguignon et al., 2016). It only seems to have occurred during a relatively short lapse of time, between 1.2 Ma and 0.9 Ma (Fourvel and Lateur, 2015).

The fossil striped hyena Hyaena prisca is sometimes described as a subspecies of the striped hyena: H. hyaena prisca. This species evolves during the Middle Pleistocene and disappears from our regions at the end of the same period. It has been reported in several Middle Pleistocene assemblages in France, including Lunel-Viel (Bonifay, 1971; Fosse, 1994), L'Escale (Bonifay, 1971; Crégut-Bonnoure, 1996b), Igue des Rameaux (Rouzaud et al., 1990) or Es-Taliens (Clot and Duranthon, 1990). The question of the phylogenetic links between $H$. prisca and $P$. perrieri is still widely debated.

The spotted fossil hyena belongs to the Crocuta genus. The specific phylogeny of this genus is still controversial: are there distinct species, i.e., do modern African and fossil European forms, correspond to C. crocuta or C. spelaea? Moreover, at least two chrono-subspecies are recognized in the fossil record: intermedia (Fig. 10, ex. Lunel-Viel) and spelaea, with an increase in size throughout time. The genus appeared in Europe during the Middle Pleistocene (around 800 ky at Calsa Selce in Italy in Sardella and Petrucci, 2012) and was the most frequent form of hyena until it disappeared, seemingly around 25,000 years BP (Fosse, 1994; Discamps, 2011; Fourvel, 2012). The cave hyena is found in many paleontological sites, among which we can cite the dens of Camiac (Guadelli, 1989b), Lunel-Viel (Fosse, 1994), Orgnac 3 (Testu, 2006) or Fouvent (Fourvel, 2012) (and see the taphonomic aspect of dens in Brugal et al., 1997).

\subsection{Felidae}

Felines are much diversified during the Pleistocene in France, with a wide taxonomic distribution (in terms of genus and species) and high variations in body size. The following species have been identified: Megantereon cultridens, Homotherium crenatidens, Dinobastis latidens, Dinofelis piveteaui, Felis lunensis, F. minuta, F. silvestris, Lynx issiodorensis, L. spelaea, L. pardinus, L. lynx, Acinonyx pardinensis, Puma pardoides, Panthera gombaszoegensis, $P$. pardus, $P$. (Leo) spelaea. Only some taxa are presented in detail below.

Recent excavations at the site of Saint-Vallier (1993-99, by M. Faure and C. Guérin), and other excavations at Senèze (2001-2006, M. Faure, C. Guérin, E. Delson), led to the identification of the carnivore species reported in earlier studies and clarified their taphonomic and paleoenvironmental conditions (Faure and Guérin, 2004). Large classical Villafranchian carnivores are present at both of these sites: Megantereon cultridens, Homotherium crenatidens, Acinonyx pardinensis. The site of Saint-Vallier contained the rare Puma pardoides (= Panthera schaubi) (Argant, 2004), which was not identified at Senèze but is still potentially present. The re-examination of the early material from Senèze indicates the probable presence of the Machairodontinae Dinofelis sp. (Argant, submitted). These two sites are chronologically close; Saint-Vallier is about $2.2 \mathrm{Ma}$ and Senèze is more recent, about $2 \mathrm{Ma}$. In the past, the site of Senèze yielded two famous whole reference skeletons, the Megantereon cultridens skeleton, curated at the Museum of Basel (NMB-Se\#311) and the Homotherium crenatidens from the Claude-Bernard University - Lyon 1 (FSL 210991) (Ballesio, 1963).

The earliest mention of the lynx is related to the terminal Pliocene (around 3.0-3.5 Ma, Perrier) and the beginning of the Early Pleistocene (around 2.0-2.5 Ma, Saint-Vallier, in Argant, 2004) by the early large-sized L. issiodorensis. The last known representatives of these species come from Untermassfeld in Germany around 0.9-1.2 Ma. Following on from the Issoire lynx, the cave lynx Lynx pardinus var. spelaea and the Boreal Pleistocene lynx L. lynx coevolves. However, the most recent study suggests an earlier appearance of the Boreal lynx with a mention at Ceyssaguet around 0.9-1.2 Ma (Tsoukala and Bonifay, 2004). The cave lynx is abundantly represented in the French sites, at Lunel-Viel (Bonifay, 1971), la Caune de l'Arago (Crégut, 1979), Malarnaud (Dufour, 1989), as well as in Vaufrey Cave (Delpech, 1988). We note in particular 89 remains in the Observatoire Cave in Monaco (Brugal et al., 2017) (Fig. 11), abundant remains at Campefiel (Bonifay, 1971) or 183 remains identified at Lazaret Cave (Valensi, 1994). The Iberian lynx L. pardinus is mainly attested in France during the most recent phases of the Pleistocene. We can cite, for example a skeleton estimated to date from the Dryas III from la Balma Abeurador (Clot and Duranthon, 1990), or another from Cabias Cave, dated to 4000 cal. BP (Rodríguez-Varela et al., 2015).

Panthera gombaszoegensis, the European jaguar, occurs in about ten French sites, including L'Escale (Bonifay, 1971) and Artenac (Tournepiche, 1984). The large-sized well-represented jaguar from la Brèche de Château (NMI = 7 including one "whole" skeleton), is one of the median Middle Pleistocene forms (Argant A. and Argant J., 2011, 2018). P. (Leo) spelaea fossilis from the Middle Pleistocene is close to an early cave lion form, characterized by its large size and powerful, well-marked muscles on the bones: Château (Argant et al., 2007) (Fig. 12), Artenac, Arago. The site of Igue des Rameaux yielded a very rich fossil series (nearly 30 individuals of all ages), resulting in the characterization of a new subspecies, $P$. (Leo) spelaea intermedia (Argant and Brugal, 2017). The Upper Pleistocene forms of $P$. (Leo) s. spelaea decrease in size until they reach the size of the present-day lion. The lion from Closeau is dated to 12,248 \pm 66 years BP (Bodu and Bemilli, 2000), and the lion from Peyrat to $10,590 \pm 70$ years BP (Fosse et al., 2017 with geochronological occurences for the southwest of France), which marks the end of the presence of 
the species in Western Europe. Between the two, the situation varies considerably, with small lions during MIS 6, and larger animals during MIS 5, undoubtedly as a result of climatic, geographic and genetic variations and specific morphotype population dynamics. It is still difficult to clarify the biochronology of $P$. spelaea during this interval.

\section{Conclusions}

France is a crossroads of differentiated climatic and biological influences during the Quaternary in Western Europe due to its geographic position and topography (mountains, rivers). It regularly underwent cycles of relative isolation and connection (e.g., with Great Britain, Italy, Northern Europe...), as a result of glacial maxima (extensions of glaciers and snow-covered zones, drops in sea level) and interglacial optima. These cycles encouraged adaptive factors, sometimes with a hint of endemism, but were also conducive to the regular introduction of new migrants or new genetic forms. These mechanisms occur in all western European regions characterized by marked geotopographic division with peninsular conditions (Iberia, Balkans, Italy, Great Britain, Scandinavia), major mountain chains (in particular the Alpine Arc), major rivers and a Germano-Polish plain linking the subcontinent to the immense Russian and Asian plains, a somewhat less heterogeneous region. This conditioned partitioning and resulted in mammalian populations (micro- to macro-faunas) with differentiated eco-evolution processes, which make biostratigraphic correlations sometimes difficult to establish. In this respect, the example of Mediterranean regions is particularly significant (e.g., Bonifay, 1996a, b; Croitor and Brugal, 2001; Brugal et al., 2004; Valensi, 2009). Most of the French Pleistocene sites are located in the southern half of the country, with possibilities of exchanges with northern European regions, and also with the south (Iberia and Italia), and do not present any particular endemism and/or particular survival of taxa, as seen in these peninsular regions. Overall, the herbivore and carnivore palaeocommunities in France are similar through time to those from the rest of Western Europe, at least in terms of ecological structure and trophic levels. However, their taxonomic composition may vary, and is more or less diversified, and some taxa are different or absent in some regions depending on geo-topography and the climatic phases of Pleistocene. Table 2 presents a summarized overall view of species distribution and sites in France during the Pleistocene subseries/subepochs.

The aim of this collective contribution was to propose a general review of the large mammal faunas in France during the Pleistocene, without claiming to be exhaustive, based in particular on recent studies and a bibliography search focusing on French studies. This overview of herbivores and carnivores from the French Pleistocene highlights the dynamism of recent research, enhanced by the revision of formerly studied sites, newly published sites or university works (Quillès, 2003; Olive, 2005; Testu, 2006; Boudadi-Maligne, 2010; Goubel, 2011; Bon, 2011; Discamps, 2011; Fourvel, 2012; Uzunidis-Boutillier, 2017; Pelletier, 2018... to quote but a few). The contribution of paleogenomic data is also increasingly vital for our taxonomic understanding of fossil populations and their phylogeographic structures. The ${ }^{14} \mathrm{C}$-AMS, U/Th-ESR dating corpus and isotopic or micro- and meso-dental wear studies has also considerably expanded. They now provide a reference framework which enables us to approach the history of species, their evolution and population dynamics more rigorously than in the past. The development of a database based on these works and complementary research approaches (such as taphonomy, Brugal, 2017), should allow us to establish an integrative view of climatic palaeoenvironments in the near future, cessions and palaeoecological (in particular body size) and evolutionary data of species in France.

\section{Author contributions}

J-.P. Brugal coordinated and planned the paper. The sections on Equids, Large Bovids, Caprids et al., Cervids, Rhinocerotids, Proboscids, Canids, Ursids, Mustelids, Hyenids, Felids were respectively writen by J.L. Guadelli, J.-P. Brugal $\lambda$ P. Magniez and R. Croitor, E.Crégut and P.Fernandez, A. Uzunidis, L.P. Brugat, M. Boudadi-Maligne, A. Argant, A. Argant and J.-P. Brugal, J.B. Fourvel and P. Fosse, A. Argant and J.B. Fourvel. P. Fosse designed Figs. 1-3 with help from J.-P. Brugal for the site list. Suppl. Information was written by J.L. Guadelli.

\section{Disclosure of interest}

The authors declare that they have no competing interest.

\section{Uncited references}

Crégut-Bonnoure, 1992c, G $\overline{\overline{\overline{\overline{ }}}}$ li and Prat, 1995, and Rabeder et al., 2004.

\section{Appendix A. Supplementary data}

Supplementary data associated with this article can be found, in the online version, at https://doi.org/10.1016/j.annpal.2019.102384.

\section{References}

Agache, R., Bourdier, F., Petit, R., 1963. Le Quaternaire de la Basse-Somme : tentative de synthèse. Bull. Soc. Géol. de France 5, 422-442.

Ambert, P., Brugal, J.-P., Houles, N., 1996. Le maar du Riège (Hérault, France) : géologie, paléontologie, perspectives de recherches. C.R. Acad. Sc. Paris sér. IIa 322, 125-132.

Antoine, P., Limondin-Lozouet, N., Auguste, P., Locht, J.-L., Galheb, B., Reyss, J.-L., Escude, , Carbonel, P., Mercier, N., Bahain, J.J., Falgueres, C., Voinchet, P., 2006. Le tuf de Caours (Somme, France) : mise en évidence d'une séquence éemienne et d'un site paléolithique associé. Quaternaire 17, 281-320.

Aouraghe, H., 1990. Les cervidés du site pléistocène Moyen d'Orgnac 3 (Ardèche, France). Quaternaire 3-4, 231-245.

Argant, A., 1991. Carnivores quaternaires de Bourgogne. Documents des Laboratoires de Géologie de Lyon 115, 1-309.

Argant, A., 1995. Un essai de biochronologie à partir de l'évolution dentaire de l'ours des cavernes. Datation du site de la Balme à Collomb (Entremont-le-Vieux, Savoie, France). Quaternaire 6 (3-4), 139-149.

Argant, A., 2004. Les Carnivores du gisement Pliocène final de Saint-Vallier (Drôme, France). In: Faure, M., Guérin, C. (Eds.), Le gisement pliocène final de Saint-Vallier (Drôme, France). Géo $=(3),, 133-182$.

Argant, A., 2018. DARA 46, 5 =

Argant, A., 2019. Les Ursidés et les Félidés de Coudoulous 1 (Tour-de-Faure, Lot). In: Jaubert, J., Brugal, J.-P., Jeannet, M., Kervazo, B., Mourre, V., Thiébaut, C. (Eds.), Coudoulous I : Séquence du Pléistocène moyen en Quercy ou comment l'Animal commande l'Homme et vice-versa, (in press).

Argant, A. 2019. The Carnivores of Senèze (Haute-Loire). In: Delson, E. (Ed.), Vertebrate Paleobiology and Paleoanthropology Book Series (submitted).

Argant, A., Argant, J., 2011. The Panthera gombaszogensis story: the contribution of the Château Breccia (Saône-et-Loire, Burgundy, France). Quaternaire HS4, 201-208, (Proceedings of the 16th International Cave Bear and Lion Symposium, Azé [Saône-et-Loire, France, 22-26 Sept. 2010]).

Argant, A., Argant, J., 2018. La Brèche à Carnivores du Pléistocène moyen de Château (Saône-et-Loire). Quaternaire 29 (3), 271-285.

Argant, A., Argant, J., Jeannet, M., Erbajeva, M., 2007. The big cats of the fossil site Château Breccia Northern Section (Saône-et-Loire, Burgundy, France): stratigraphy, palaeoenvironment, ethology and biochronological dating. Cour. Forsch-Inst. Senckenberg 259, 121-140.

Argant, A., Brugal, J.-P., 2017. The Cave Lion Panthera (Leo) spelaea and its Evolution: Panthera spelaea intermedia nov. subspecies. Acta Zoologica Cracoviensia 60 (2), 59-104, (Proceedings of the 22nd International Cave Bear Symposium, Kletno, Poland, 21-25 september 2016, Marciszak, A., Ed.). 
Argant, A., Crégut-Bonnoure, , 1996. Ordre des Carnivores : famille des Ursidés. In: Guérin, C., Patou-Mathis, M. (Eds.), Les grands mammifères plio-pléistocènes d'Europe. Masson, Paris, pp. 167-179.

Argant, A., Elalouf, J.-M., Bon, C., 2012. OURSALP programme: contribution of the Baré d'Onnion Cave (Haute-Savoie, France) and first conclusions of the programme. Braunschw. Naturkdl. Schr. 11, 3-11.

Argant, A., Griggo, C., Philippe, M., Bintz, P., Picavet, R., Fourgous, B., Tillet, T., Argant, J., 2018. Bilan du programme OURSALP - Exemple de l'ours fossile du Scialet de la Décroissance à Corrençon-en-Vercors (Isère, France). In: Bintz, P., Martin, L., Picavet, R., (Eds.), L'homme dans les Alpes, de la pierre au métal. EDYTEM 20, 29-46, (Actes de la table ronde de l'AVDPA, Villard-de-Lans [Isère], 13-15 oct. 2016).

Argant, A., Griggo, C., Philippe, M., Fourgous, B., Juif, D., Picavet, R., Argant, J., 2019. Spéléologie et paléontologie : le Programme OURSALP. Exemples du gouffre de la Nisotte (L'Hôpital-du-Grosbois, Doubs) et du Scialet de la Décroissance (Corrençon-en-Vercors, Isère). Spelunca Mémoires 38, 139-146, (Actes du premier colloque francophone " Histoire de désob' », Azé [Saône-et-Loire], 9 et 10 mars 2019)

Arbogast, R.-M., Clavel, B., Meniel, P., Yvinec, J.-H., Lepetz, S., 2002. Archéologie du cheval. Des origines à la période moderne en France. Éditions Errances, Collection Hespérides, Paris

Auguste, P., 1995. Cadres biostratigraphiques et paléoécologiques du peuplement humain dans la France septentrionale durant le Pléistocène, apport de l'étude paléontologique des grands mammifères du gisement de Biache-Saint-Vaast (Pas-de-Calais). Institut de Paléontologie Humaine, Paris, (Unpublished PhD thesis).

Auguste, P., 2009. Évolution des peuplements mammaliens en Europe du nord-ouest durant le pléistocène moyen et supérieur. Le cas de la France septentrionale. Quaternaire 20 (4), 527-550.

Auguste, P., Carpentier, G., Lautridou, J.-P., 2003. La faune mammalienne de la basse terrasse de la Seine à Cléon (Seine- Maritime, France) : interprétations taphonomiques et biostratigraphiques. Quaternaire 14, 5-14.

Auguste, P., Cliquet, D., Hervieu, G., Liouville, M., Louguet, S., Monnier, J.-L., Rorive, S., 2005. Stratégies de subsistance dans l'Ouest de la France au Pléistocène moyen et supérieur : acquisition et traitement des matières premières d'origines minérale et animale à Piégu (Côtes d'Armor), Ranville (Calvados) et au Mont-Do (Ille et Vilaine). In: Molines, N., Moncel, M.-H., Monnier, J.-L. (Eds.), Les Premiers Peuplements En Europe. BAR Internat. Series, Oxford, pp. 519-532.

Ballesio, R., 1963. Monographie d'un Machairodus du gisement villafranchien de Senèze : Homotherium crenatidens Fabrini. Trav. des Laboratoires de Géologie de Lyon 9, 1-129.

Beden, M., 1979. Les éléphants (Loxodonta et Elephas) d'Afrique orientale : systématique, phylogénie, intérêt bio-chronologique. Université de Poitiers, (unpublished $\mathrm{PhD}$ state thesis)

Belgrand, E., 1883. La Seine : I. Le bassin parisien aux âges antéhistoriques. Imprimerie Nationale, Paris, France.

Bellai, D., 1998. Le cheval du gisement pléistocène moyen de la Caune de 1'Arago (Tautavel, Pyrénées Orientales, France). Quaternaire 9, 325-335.

Bellai, D., 1995. Techniques d'exploitation du cheval à la Caune de l'Arago (Tautavel, Pyrénées-Orientales). Paléo 7, 139-155.

Bennett, E., Champlot, S., Peters, J., Arbuckle, B., Guimaraes, S., Pruvost, M., Bar-David, S., Davis, S.J.M., Gautier, M., Kaczensky, P., Kuehn, R., Mashkour, M., Morales-Muñiz, A., Pucher, E., Tournepiche, J.-F., Uerpmann, H.-P., Balasescu, A., Germonpré, M., Gündem, C., Geigl, E.-M., 2017. Taming the late Quaternary phylogeography of the Eurasiatic wild ass through ancient and modern DNA. Plos ONe 12 (4), e 0174216

Bignon, O., 2003. Diversité et exploitation des équidés au Tardiglaciaire en Europe oc cidentale. Implications pour les stratégies de subsistance et les modes de vie au Magdalénien et à l'Azilien ancien du Bassin parisien. Univiversité de Paris X-Nanterre, (2 vol., unpublished $\mathrm{PhD}$ thesis).

Bignon, O., Baylac, M., Vigne, J.-D., Eisenmann, V., 2005. Geometric morphometrics and the population diversity of Late Glacial horses in Western Europe (Equus caballus arcelini): phylogeographic and anthropological implications. J. of Arch. Sc. 32, 375-391.

Bignon, O., Eisenmann, V., 2006. Western European Late Glacial horse diversity. In: Mashkour, M. (Ed.), Equids in Time and Space, Papers in Honour of Véra Eisenmann. Oxbow Books, Barnsley, pp. 161-171.

Billia, E.M., Petronio, C., 2009. Selected records of Stephanorhinus kirchbergensis (Jager, 1839) (Mammalia, Rhinocerotidae) in Italy. Boll. Soc. Paleont. Ital. 48, 21-32.

Bocherens, H., 2008. Stable isotopes investigations of Late Glacial and Early Holocene brown bear finds from caves in the alpine regions. In: Döppes, D. (Ed.). In: 14th International Cave Bear Symposium, Appenzell, Switzerland, 18-22 Sept. 2008. pp. 18-20.

Bœuf, O., 1997. À propos de Chilhac, Senèze, Blassac-la-Girondie (Haute-Loire), gisements du Pliocène terminal, leur intérêt biochronologique. In: Aguilar, J.-P., Legendre, S., Michaux, J., (Eds.). In: Actes du Congrès BiochroM'97, Mém./Tr E.P.H.E., Montpellier, 21. pp. 661-668.

Bodu, P., Bemilli, C., 2000. Le gisement du Closeau à Rueil-Malmaison (Hauts-de-Seine) : le lion est-il mort ce soir ? In: Cupillard, C., Richard, A., (Eds.), Les derniers chasseurs-cueilleurs d'Europe occidentale. Presses Univ. Franc-Com- toises, Annales littéraires 699 (1), 173-185, (Actes du Coll. Internat., Besançon, oct. 1998).

Bogros, D., 1989. Des hommes, des chevaux, des équitations. Favre-Caracole, Lausanne, Suisse.

Boivin, P., Barbet, P., Bœuf, O., Devouard, B., Besson, J.-C., Henot, J.-M., Devidal, J.-L., Constantin, C., Charles, L., 2010. Geological setting of the Early Pleistocene fossil deposits of Chilhac (Haute-Loire, France). Quat. Intern. 223/224, 107-115.

Bon, C., 2011. Contribution à la Paléogénétique et de la Paléogénomique à l'étude des sites archéologiques. Univiversité de Paris-Sud 11, (Unpublished $\mathrm{PhD}$ thesis).

Bonifay, M.-F., 1960. Aperçu sur la faune de la grotte de Rigabe. Gallia préhistoire 3 , $39-46$.

Bonifay, M.F., 1971. Carnivores quaternaires du Sud-Est de la France. Mémoire du Muséum Naturelle Histoire Naturelle série C, Paris, France.

Bonifay, M.-F., 1973. Dicerorhinus etruscus Falconer du Pléistocène moyen des grottes du Lunel-Viel (Hérault). Annales Paléontologiques 59, 79-112.

Bonifay, M.-F., 1974-1975. Hemitragus bonali Harlé \& Stehlin, Caprini de la grotte de l'Escale (Saint-Estève-Janson, Bouches-du-Rhône). Quaternaria 18, 215-302.

Bonifay, M.-F., 1980. Le Cheval du pléistocène moyen des grottes de Lunel-Viel (Hérault), Equus mosbachensis palustris. Gallia préhistoire 23, 233-281.

Bonifay, M.-F., 1981. Les Praemegaceros du Pléistocène moyen de la grotte de l'Escale à Saint-Esteve-Janson (Bouches-du-Rhône) : leur intérêt dans le contexte Biostratigraphique européen. Bull. A.F.E.Q. 3-4, 109-120.

Bonifay, M.-F., 1991. Equus hydruntinus Regalia minor n. ssp. from the caves of Lunel-Viel (Hérault, France). In: Meadow, R.-H., Uerpmann, H.-P., (Eds.), Equids in the Ancient World. Beihefte zum Tübinger Atlas des Vorderen Orients: Wiesbaden A19/2, 178-216.

Bonifay, M.-F., 1996. Histoire et dynamique des grandes faunes sud-européennes plio-pléistocènes. In: 121é congr. C.T.H.S., Nice, Echanges et diffusion dans la préhistoire In méditerranéenne, C.T.H.S., Paris, 105-112.

Bonifay, M.-F., 1996. The importance of mammalian faunas from the early Middle Pleistocene of France. In: Turner, C. (Ed.), The early Middle Pleistocene in Europe, Balkema, Rotterdam, The Netherland, pp. 255-262.

Bonifay, M.-F., Brugal, J.-P., 1996. Biogéographie et biostratigraphie des grandes faunes du Pléistocène inférieur et moyen en Europe du Sud : apport des gisements français. Paléo 8, 19-30.

Bonnet, A., 1980. Le gisement à faune à Machairodus de la Sartanette (Remoulins, Gard). Nouveau repère biostratigraphique antémindelien. In: Chaline, J., (Ed.), Problèmes de stratigraphie quaternaire en France et dans les pays limitrophes. Bull. A.F.E.Q suppl. 1, 348-350.

Bouchud, J., 1972. Les grands herbivores Rissiens des « Abîmes de la Fage » en Corrèze (Cervidés, Bovidés, Capridés, Rupicaprines, Suidés et Équidés). Nouv. Arch. Mus. Hist. nat. Lyon 10, 33-59.

Boudadi-Maligne, M., 2010. Les Canis pléistocènes du Sud de la France : approche biosystématique, évolutive et biochronologique. Univiversité de Bordeaux 1, (Unpublished $\mathrm{PhD}$ thesis)

Boudadi-Maligne, M., 2012. Une nouvelle sous-espèce de loup (Canis lupus maximus nov. subsp.) dans le Pléistocène supérieur d'Europe occidentale. Comptes Rendus Palevol 11 (7), 475-484.

Boulbes, N., 2009. Étude comparée de la denture d'Equus hydruntinus (Mammalia, Perissodactyla) dans le sud-est de la France. Implications biogéographiques et biostratigraphiques. Quaternaire 20 (4), 449-465.

Boulbes, N., 2010. Le cheval de Romain-la-Roche, Equus achenheimensis (Mammalia Perissodactyla) : contribution à la biochronologie des équidés caballins au Pléistocène moyen. Rev. de Paléobiologie Genève 29 (2), 747-770.

Bourgeois, G., Philippe, M., 2017. Présence du glouton Gulo gulo (Mustelidae, Carnivora) dans le gisement pléistocène moyen de La Fage-aven II, à Noailles (Corrèze, France). Paléo 28, 215-225.

Bourguignon, L., Crochet, J.-Y., Capdevila, R., Ivorra, J., Antoine, P.-O., Agusti, J., Barsky, D., Blain, H.-A., Boulbes, N., Bruxelles, L., Claude, J., Cochard, D., Filoux, A., Firmat, C., Lozano-Fernandez, I., Magniez, P., Pelletier, M., Rios-Garaizar, J., Testu, A., Valensi, P., De Weyer, L., 2016. Bois-de-Rique (Lézignan-la-Cèbe, Hérault): a late Early Pleistocene archeological occurrence in southern France. Quat. Internat. 393, 24-40.

Brugal, J.-P., 1981. Balaruc VII (Sète, Hérault). Un nouveau remplissage de fissure de la fin du Pléistocène moyen. Quaternaria 23, 99-141.

Brugal, J.-P., 1983. Application des analyses multidimensionnelles à l'étude systématique du squelette des membres des Grands Bovidés Pléistocènes (Grottes de Lunel-Viel, Hérault), Perspectives évolutives. Univiversité d'Aix-Marseille II, Fac. Sciences Luminy-Marseille, (Unpublished PhD thesis)

Brugal, J.-P., 1985. Le Bos primigenius Boj., 1827 du Pléistocène moyen des grottes de Lunel-Viel (Hérault). Bull. Mus. Anthr. Préh. Monaco 28, 7-62.

Brugal, J.-P., 1994-1995. Le Bison (Bovinae, Artiodactyla) du gisement Pléistocène moyen ancien de Durfort (Gard, France). Bull. Mus. nat. Hist. Nat. Paris 16 (2-4), 349-381.

Brugal, J.-P., 1999. Étude des populations de grands Bovidés européens : intérêt pour la connaissance des comportements humains au Paléolithique. In: Brugal, J.P., David, F., Enloe, J., Jaubert, J. (Eds.), Le Bison, gibier et moyen de subsistance des hommes du Paléolithique aux paléoindiens des grandes plaines. APDCA Antibes, pp. 85-103. 
Brugal, J.-P., 2016. Paléohistoire d'un crane de bison aurignacien à Regismont-le-Haut. Paléo 27, 65-82.

Brugal, J.-P. (Ed.), 2017. Taphonomies. EAC, Coll. Sc. Arch, Paris, France.

Brugal, J.-P., Beauval, C., Castel, J.C., Costamagno, S., Coumont, M.P., Fournier, J., Gerbe, M., Griggo, C., Juillard, F., Kuntz, D., 2013. Les peuplements mammalien au Pléistocène moyen et supérieur en Quercy. In: Jarry, M., Brugal, J.-P., Ferrier, C. (Eds.), Modalité d'occupation et exploitation des milieux au Paléolithique dans le Sud-Ouest de la France : l'exemple du Quercy. Paléo suppl. 4, 145-158.

Brugal, J.-P., Boudadi-Maligne, M., 2011. Quaternary small to large canids in Europe: taxonomic status \& biochronological contribution. Quatern. Int. 243, 171-182.

Brugal, J.-P., Bridault, A., Guadelli, J.L., Vigne, J.D., 2004. Distribution des grands mammifères en France aux deux derniers extrêmes climatiques (18 ka et 8 ka). BAR International Series 1271, 39-48.

Brugal, J.-P., Croitor, R., 2007. Evolution, ecology and biochronology of herbivore as sociations in Europe during the last 3 millions years. Quaternaire 18 (2), 129-151.

Brugal, J.-P., Lacombat, F., 2004-2005. Bison schoetensacki (Freudenberg, 1910). In: Lacombat, F., (Ed.), Les grands Mammifères fossiles du Velay, Les collections paléontologiques du Plio-Pléistocène du Musée Crozatier. Annales des Amis du Musée Crozatier : Le Puy en Velay, France 13/14, 113-115.

Brugal, J.-P., Fosse, P., Guadelli, J.-L., 1997. Comparative study of bones assemblages made by recent and plio-pleistocene Hyaenids (Hyaena, Crocuta). In: Hannus, L.A., Winham, R.P., (Eds.), Proceedings of the 1993 Bone Modification Conference, Hot Springs, South Dakota. Archeology Lab., Augustana College, occ.publ. $1,158-187$.

Brugal, J.-P., Fosse, P., 2005. Les grands bovidés (Bison cf. schoetensacki) du site pléistocène moyen de La Vayssière (Aveyron, France). In: Crégut-Bonnoure, E. (Ed.), Les Ongulés Holarctiques du Pliocène et du Pléistocène. Quaternaire H.S. 2, $75-80$.

Brugal, J.-P., Fourvel, J.-B., Fosse, P., 2017. Premières observations sur les guildes de carnivores de la grotte de l'Observatoire (Principauté de Monaco). Bull. Mus. Anthr. Préh. Monaco 57, 35-48.

Burke, A., Eisenmann, V., Amblerc, G.K., 2003. The systematic position of Equus hydruntinus, an extinct species of Pleistocene equid. Quat. Res. 59, 459-469.

Castel, J.C., Madelaine, S., 2006. Quelques éléments remarquables de la faune du Solutréen de Laugerie-Haute (Les-Eyzies-de-Tayac, Dordogne). Paléo 18, 275-584.

Castel, J.C., Coumont, M.P., Boudadi-Maligne, M., Prucca, A., 2010. Rôle et origine des grands carnivores dans les accumulations naturelles. Le cas des loups (Canis lupus) de l'Igue du Gral (Sauliac-sur-Célé Lot, France). Rev. Paléobiol. 29, 411-415.

Chaix, L., Desse, J., 1981. Contribution à la connaissance de l'élan (Alces alces L.) postglaciaire du Jura et du Plateau suisse. Corpus de mesures. Quartär 31-32, 139-190.

Clot, A., Marsan, G., 1986. La grotte du Cap de la Bielle à Nestier (Hautes-Pyrénées). Fouilles M. Debeneaux (1960). Gallia Préhistoire 29, 63-141.

Clot, A., Duranthon, F. (Eds.), 1990. Les mammifères fossiles du Quaternaire dans les Pyrénées. Muséum Toulouse.

égut, E., 1979. La faune de mammifères du Pléistocène moyen de la Caune de l'Arago à Tautavel, Pyrénées-Orientales. Univiversité de Provence, Marseille (Unpublished PhD thesis),

Crégut, E., 1980 La faune de Mammifères du gisement pléistocène moyen de la Caune de l'Arago (Tautavel, Pyrénées-Orientales, France). C. R. Acad. Sc. Paris, D 290, 751-754.

Crégut-Bonnoure, E., 1980. Equus mosbachensis tautavelensis nov. subsp., un nouvel equidae (Mammalia, Perissodactyla) du gisement pléistocène moyen anté-rissien de la Caune de l'Arago (Tautavel, Pyrénées-orientales, France). Géobios 13, 121-127.

Crégut-Bonnoure, E., 1984. The Pleistocene Ovibovinae of Western Europe. Biology Paper of the University of Alaska, special reports 4, 136-144.

Crégut-Bonnoure, E., 1987. Caractères distinctifs du carpe et du tarse d'Hemitragus et de Capra (Mammalia, Bovidae, Caprinae). Bull. Mus. Anthrop. Préhist. de Monaco 30, 43-94.

Crégut-Bonnoure, E., 1988. Balaruc VII (Sète, Hérault), un nouveau gisement à Hemitragus Hodgson, 1841 (Mammalia, Bovidae). Intérêt biostratigraphique du genre et de Capra Linné, 1758. C. R. Acad. Sc. Paris 306 (II), 255-258.

Crégut-Bonnoure, E., 1989. Un nouveau Caprinae, Hemitragus cedrensis nov. sp. (Mammalia, Bovidae), des niveaux pléistocènes moyens de la grotte des Cèdres (Le Plan d'Aups, Var). Intérêt biogéographique. Géobios 22 (5), 653-663.

Crégut-Bonnoure, E., 1992. Pleistocene tahrs, ibexes and chamois of France. In: Spitz, F., Janeau, G., Gonzalez, G., Aulanier, S., (Eds.). In: Actes du Symposium international d'Étude des Ongulés sauvages 'Ongulés 91', S.F.E.P.M.-I.R.G.M., Paris-Toulouse, pp. 49-56.

Crégut-Bonnoure, E., 1992. Dynamics of Bovid migration in Western Europe during the Middle and the Late Pleistocene. Cour. Forschungsinstitut Senckenberg 153, $177-185$.

Crégut-Bonnoure, E., 1992 Les Caprinae (Mammalia, Bovidae) du Pléistocène d'Europe. Intérêt biostratigraphique, paléoécologique et archéozoologique. Mém. Soc. Géol. de France n.s. 160, 85-93.

Crégut-Bonnoure, E., 1992 Intérêt biostratigraphique de la morphologie dentaire de Capra (Mammalia, Bovidae). Ann. Zool. Fenn. 28, 273-290.
Crégut-Bonnoure, E., 1995. Les grands mammifères. In: Defleur, A., Crégut-Bonnoure, E., (Eds.), Le gisement Paléolithique moyen de la grotte des Cèdres (Var). Doc. Arch. Fr. 49, 54-142.

Crégut-Bonnoure, , 1996. Ordre des Carnivores. Sous-famille des Lutrinae. In: Guérin, C., Patou-Mathis, M. (Eds.), Les grands mammifères plio-pléistocènes d'Europe, Masson, Paris, pp. 193-195.

Crégut-Bonnoure, , 1996. Famille des Hyaenidae. In: Guérin, C., Patou-Mathis, M. (Eds.), Les grands mammifères plio-pléistocènes d'Europe, Masson, Paris, pp. 215-223.

Crégut-Bonnoure, E., 2002. Les Ovibovini, Caprini et Ovini (Mammalia, Artiodactyla, Bovidae, Caprinae) du Plio-Pléistocène d'Europe, systématique, évolution et biochronologie. Université de Lyon I, 1-429, (Unpublished PhD state thesis).

Crégut-Bonnoure, E., 2006. European Ovibovini, Ovini, Caprini (Caprinae, Mammalia) from the Plio-Pleistocene: new interpretations. In: Maul, L.C., Kahlke, R.D., Mazza, P., (Eds.), Late Neogene and Quaternary biodiversity and evolution, Regional developments and interregional correlations. Cour. Forschungsinstitut Senckenberg 256, 139-158.

Crégut-Bonnoure, E., 2007. Apport des Caprinae et Antilopinae (Mammalia, Bovidae) à la biostratigraphie du Pliocène terminal et du Pléistocène d'Europe. Quaternaire 8 (1), 73-97.

Crégut-Bonnoure $\overline{\bar{\equiv}}$ 08. Mém. S.P.F. Paris XLVI, 78-80

Crégut-Bonnoure, ., 2009. Biochronologie et grands Mammifères au Pléistocène moyen et supérieur en Europe occidentale, l'apport des genres Hemitragus et Capra. Quaternaire 20 (4), 481-508.

Crégut-Bonnoure, E., Boulbes, N., Daujeard, C., Fernandez, P., Valensi, P., 2010. Nouvelles données sur la grande faune de l'Eémien dans le Sud-Est de la France. Quaternaire 21 (1), 227-248.

Crégut-Bonnoure, E., Boulbes, N., Guérin, C., Pernaud, J., Tavoso, A., Cammas, R., 2011. Le contexte géomorphologique et faunique de l'Homme de Montmaurin (Haute-Garonne). Préhist. Médit. 1, 35-86.

Crégut-Bonnoure, E., Dimitijevič, V., 2006. Megalovis balcanicus sp. nov. and Soergelia intermedia sp. nov. (Mammalia, Bovidae, Caprinae), new Ovibovini from the Early Pleistocene of Europe. Rev. Paleobiol. 25 (2), 423-473.

Crégut-Bonnoure, E., Fernandez, P., 2004. Tahrs, Chamois et Bouquetins, des espèces importantes pour la biochronologie des sites vauclusiens. In: Avignon, B. (Ed.) Vaucluse préhistorique : le territoire, les hommes, les cultures et les sites. p. 69

Crégut-Bonnoure, E., Fernandez, P., 2018. Perspectives morphométriques et phylogéniques du genre Capra au Pléistocène (Mammalia, Artiodactyla, Caprinae). Quaternaire 29 (3), 243-254.

Crégut-Bonnoure, E., Gagnière, S., 1981. Sur la présence de Saiga tatarica (Mammalia, Artiodactyla) dans le dépôt pléistocène de la grotte de la Salpêtrière (Rémoulins, Gard). Nouv. Arch. Mus. Hist. nat. Lyon suppl. 19, 37-42.

Crégut, E., Guérin, C., 1979. Première découverte en Europe sud-occidentale de Praeovibos priscus (Mammalia, Artiodactyla, Ovibovinae) dans le gisement anté-rissien de la Caune de l'Arago (Tautavel, Pyrénées-Orientales, France). Géobios 12 (3), 459-465.

Crégut-Bonnoure, E., Guérin, C., 1996. Ordre des Artiodactyles. Famille des Bovidae. In: Guérin, C., Patou-Mathis, M. (Eds.), Les grands Mammifères plio-pléistocènes d'Europe. Masson, Paris, pp. 62-106.

Crégut-Bonnoure, E., Paccard, M., 1997. La faune à Saiga tatarica de Chinchon I à Saumanes (Vaucluse). Quaternaire 8 (4), 391-407.

Crégut-Bonnoure, E., Spassov, N., 2002. Hemitragus orientalis nov. sp. (Mammalia, Artiodactyla, Bovidae), un nouveau taxon d'Europe orientale. Rev. Paléobiol. 21 (2), 553-573.

Crégut-Bonnoure, E., Valli, A., 2004. Les Bovidae du site Villafranchien supérieur de In: Faure, M., Guérin, C., (Eds.), Le gisemnt pliocène final de Saint-Vallier (Drome, France). Géobios mém. spéc 26, 233-258.

Crochet, J.Y., Gence, J., Boulbes, N., Boutié, P., Cretin, C., Crégut-Bonnoure, E., Duzer, D., Jolly, D., Laudet, F., Lefèbvre, D., Mourer-Chauviré, C., Rousselières, F., Thouand, E., 2007. Nouvelles données paléoenvironnementales dans le Sud de la France vers 30000 ans ${ }^{14} \mathrm{C} \mathrm{BP}: \bar{\equiv}$ le la grotte Marie (Hérault). C.R. Palevol 6, 241-251.

Croitor, R., 2006. Early Pleistocene small-sized deer of Europe. Hell. J. of Geosc. 41, 89-117.

Croitor, R., 2006. Taxonomy and systematics of large-sized deer of the genus Praemegaceros Portis, 1920 (Cervidae, Mammalia). Cour. Forschungsinstitut Senckenberg 256, 91-116.

Croitor, R., 2009. Systematical position and evolution of the Genus Arvernoceros (Cervidae, Mammalia) from Plio-Pleistocene of Eurasia. Oltenia. Studiile şi comunicări. Stiintele Naturii 25, 375-382.

Croitor, R., 2018. Plio-Pleistocene Deer of Western Palearctic: Taxonomy, Systematics, Phylogeny. Chisinau: Inst. Zool. of the Acad. of Sc. of Moldova, Elan Poligraf, Moldova.

Croitor, R., Bonifay, M.-F., 2001. Étude préliminaire des cerfs du gisement pléistocène inférieur de Ceyssaguet (Haute-Loire). Paléo 13, 129-144.

Croitor, R., Bonifay, M.-F., Bonifay, E., 2006. Origin and evolution of the Late Pleistocene island deer Praemegaceros (Nesoleipoceros) cazioti (Depéret) from Corsica and Sardinia. Bull. Mus. Anthr. Préh. Monaco 46, 35-68.

Croitor, R., Bonifay, M.F., Brugal, J.-P., 2008. Systematic revision of the endemic deer Haploidoceros n. gen. mediterraneus (Bonifay, 1967) (Mammalia, Cervidae) 
from the Middle Pleistocene of Southern France. Paläontologische Zeitschrift 82, 325-346.

Croitor, R., Brugal, J.-P., 2001. News insights concerning Early Pleistocene cervids and bovids in Europe: dispersal and correlation. Cour. Forsch. -Inst. Senckenberg $259,47-59$.

Croitor, R., Obada, T., 2017. On the presence of Late Pleistocene wapiti, Cervus canadensis Erxleben, 1777 (Cervidae, Mammalia) in the Palaeolithic site Climăuti II (Moldova). Contr. to Zoology 86 (4), 273-296.

Cohen, K.M., Gibbard, P.L., $2011_{2}$ Global chronostratigraphical correlation table for

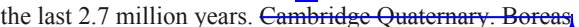

Cucchi, T., Mohaseb, A., Peigné, S., Debue, K., Orlando, L., Mashkour, M., 2017. Detecting taxonomic and phylogenetic signals in equid cheek teeth: towards new palaeontological and archaeological proxies. The Royal Society 4 (4).

Delpech, F., 1983. Les faunes du Paléolithique supérieur dans le Sud-Ouest de la France. Cahiers du Quaternaire 6, 1-453.

Delpech, F., 1988. Les grands Mammifères de la grotte Vaufrey à l'exception des Ursidés. In: Rigaud, J.P., (Ed.), La grotte Vaufrey. Mém. S.P.F. Paris 19, 213-289.

Delpech, F., Le Tensorer, J.M., Pineda, R., Prat, F., 1978. Un nouveau gisement du Pléistocène moyen, Camp-de-Peyre à Sauveterre-la-Lémance (Lot-et-Garonne). C. R. Acad. Sc. Paris D (286), 1101-1103.

Defleur, A., Crégut-Bonnoure, E., Desclaux, E., Thinon, M., 2001. Présentation paléo-environnementale du remplissage de la Baume Moula-Guercy à Soyons (Ardèche), implications paléoclimatiques et chronologiques. L'Anthropologie 105, 369-408.

Discamps, E., 2011. Hommes et hyènes face aux recompositions des communautés d'Ongulés (MIS 5-3) : Éléments pour un cadre paléoécologique des sociétés Paléolithique moyen et supérieur ancien d'Europe de l'Ouest. Université de Bordeaux 1, (Unpublished PhD thesis).

Dive, J., Eisenmann, V., 1991. Identification and discrimination of first phalanges from Pleistocene and modern Equus, wild and domestic. In: Meadow, R.H., Uerpmann, H.P., (Eds.), Equids in the ancien World. Beihefte zum Tübinger Atlas des Vorderen Orients Wiesbaden A, 278-333.

Dufour, R., 1989. Les carnivores pléistocènes de la caverne de Malarnaud (Ariège) (Collection E. Harlé, Muséum d'Histoire Naturelle de Bordeaux). Univ. de Bordeaux I, (Unpublished DES thesis).

Dujardin, V., Tymula, S., 2005. Relecture chronologique de sites paléolithiques et épipaléolithiques anciennement fouillés en Poitou-Charentes. Actes du $129^{\mathrm{e}}$ Congrès des Travaux historiques et scientifiques, Besançon. Bull. et Mém. S.P.F. 102 (4), 771-788.

Duvernois, M.-P., 1990. Les Leptobos (Mammalia, Artiodactyla) du Villafranchien d'Europe Occidentale. Documents des laboratoires de Géologie de Lyon 1I3, $1-181$

Duvernois, M.-P., 1992. Mise au point sur le genre Leptobos (Mammalia, Artiodactyla, Bovidae), implications biostratigraphiques et phylogénétiques. Geobios 25 (1), $155-166$.

Duvernois, M.P., Guérin, C., 1989. Les Bovidae (Mammalia, Artiodactyla) du Villafranchien supérieur d'Europe Occidentale. Geobios 22, 339-379.

Eisenmann, V., 1980. Les Chevaux (Equus sensu lato) fossiles et actuels : crânes et dents jugales supérieures. Cahier de Paléontologie

Eisenmann, V., 1981. Études des dents jugales inférieures des Equus (Mammalia, Perissodactyla) actuels et fossiles. Palaeovertebrata Montpellier 10 (3-4),

Eisenmann, V., 1984. Sur quelques caractères adaptatifs du squelette d'Equus et leurs implications paléoécologiques. Bull. Mus. Nat. Hist. Nat. Paris 6 (2), 185-195.

Eisenmann, V., 1988. Tentative typology and biostratigraphy of some middle and late pleistocene western European horses. Il Quaternario 1 (2), 103-109.

Eisenmann, V., 1991. Les Chevaux quaternaires européens (Mammalia, Perissodactyla). Taille, typologie, biostratigraphie et taxonomie. Géobios 24 (6), 747-759.

Eisenmann, V., 1991. Proportions squelettiques de Chevaux quaternaires et actuels. Géobios 13, 25-32.

Eisenmann, V., 1998. Quaternary Horses: possible candidates to domestication. The Horse: its domestication, diffusion and role in past communities, Proceed. of the XIII International Congress of UISPP, Forli, Italia, 8-14 Sept. 1996, Vol. 6 (1/3). ABACO Ed, 27-36.

Eisenmann, V., 2006. Discriminating Equus skulls: the Franck's Index and the new Palatal Index. In: Mashkour, M. (Ed.), Equids in Time and Space, Papers in Honour of Véra Eisenmann, Oxbow Books, Barnsley, UK, pp. 172-182.

Eisenmann, V., 2006, Pliocene and Pleistocene Equids: palaeontology versus molecular biology. Cour. Forsch. -Inst. Senckenberg 256, 71-89.

Eisenmann, V., Arbogast, R.-M., 1997. Le cheval néolithique de Chalain 3. In: Petrequin, P., (Éd.), Les sites littoraux néolithiques de Clairvaux-les-Lacs et de Chalain (Jura). Maison des Sciences de l'Homme: Paris III (2), 693-702.

Eisenmann, V., Beckouche, S., 1986. Identification and discrimination of metapodials of modern and Pleistocene Equus, wild and domestic. In: Meadow, R.H., Uerpmannn, H.P., (Eds.), Equids in the ancien World. Beihefte zum Tübinger Atlas des Vorderen Orients Wiesbaden A (I, 19/1), 117-163.

Eisenmann, V., Crégut-Bonnoure, E., Moigne, A.-M., 1985. Equus mosbachensis et les grands chevaux de la Caune de l'Arago. Bull. Mus. Nat. Hist. Nat Paris 7 (2), $157-173$

Eisenmann, V., David, F., 1990. Les chevaux des niveaux XI er Xb-c de la grotte du Renne à Arcy-sur-Cure (Yonne). In Paléolithique moyen récent et Palé olithique supérieur ancien en Europe. Mém. du Musée de Préhist. d'Île-de-France 3, 325-328.

Eisenmann, V., David, F., 2002. Évolution de la taille des chevaux d'Arcy-sur-Cure et de quelques autres chevaux quaternaires. Gallia Préhistoire suppl. 34, 97-104.

Eisenmann, V., Guérin, C., 1984. Morphologie fonctionnelle et environnement chez les Périssodactyles. Géobios mém. spéc. 8, 69-74.

Eisenmann, V., Karchoud, A., 1982. Analyses multidimensionnelles des métapodes d'Equus. Bull. Mus. Nat. Hist. Nat. Paris 4 (1-2), 75-103.

Eisenmann, V., Patou, M., 1980. La faune de la grotte de Félinès-Termenès (Aude) Résultats préliminaires et étude détaillée des restes d'Equus hydruntinus. L'Anthropologie 84 (4), 633-649.

Evin, J., Marien, G., Pachiaudi, C., 1978. Lyon Natural Radiocarbon Measurements VII. Radiocarbon 20, 19-57.

Fabre, M., 2017. Environnement et subsistance au Pléistocène supérieur au Luxembourg et dans l'Est de la France. Étude ostéologique des gisements d'Oetrange (Lux.), de Vergisson II (Saône-et-Loire, Fr.) et de la Baume de Gigny (Jura, Fr.). Dossiers d'Archéologie, XVI, Centre National de Recherches en Archéologie, Mus. Nat. d'Hist. Nat, Luxembourg.

Faure, M., Guérin, C., 2004. Présentation du site et historique des recherches. In: Faure, M., Guérin, C., (Eds.), Le gisement pliocène final de Saint-Vallier (Drôme, France). Géobios 26 (3), 1-16.

Fernandez, P., 2001. Étude paléontologique et archéozoologique des niveaux d'occupations moustériens au Bau de l'Aubesier (Monieux, Vaucluse) : implications biochronologiques et palethnologiques. Université Claude-Bernard Lyon 1, (Unpublished $\mathrm{PhD}$ thesis).

Fernandez, P., 2006. Étude paléontologique des ongulés du gisement moustérien du Bau de l'Aubesier (Vaucluse, France) : morphométrie et contexte biochronologique. Documents des laboratoires de Géologie de Lyon 161, 1-231.

Fernandez, P., 2019. Coudoulous I (Tour-de-Faure, Lot) : une nouvelle séquence à Hemitragus cedrensis Crégut-Bonnoure, 1989 (Bovidae, Caprinae) dans le Sud-Ouest de la France. In: Jaubert, J., Brugal, J.-P., Jeannet, M., Kervazo, B., Mourre, V., Thiébaut, C. (Eds.), Coudoulous I: Séquence du Pléistocène moyen en Quercy ou comment l'Animal commande l'Homme et vice-versa, (in press).

Fernandez, P., Bonenfant, C., Gaillard, J.M., Legendre, S., Monchot, H., 2017. Life tables and Leslie matrices for mammalian cohorts in different paleobiological contexts during the Pleistocene. In: Brugal, J.-P. (Ed.), TaphonomieS. EAC, Coll. Sc. Arch., Paris, pp. 477-497.

Fernandez, P., Crégut-BonnoureF E., 2007. Les Caprinae (Rupicaprini, Ovibovini, Ovini et Caprini) de la séquence pléistocène de Kozarnika (Bulgarie du Nord) morphométrie, biochronologie et implications phylogéniques. Rev. de Paleobiologie Genève 26 (2), 425-503.

Fernandez, P., Guadelli, J.-L., Fosse, P., 2006. Applying dynamics and comparing life tables for Pleistocene Equidae in anthropic (Bau de l'Aubesier, Combe-Grenal) and carnivore (Fouvent) contexts with modern feral horse populations (Akagera, Pryor Mountain). J. of Arch. Sc. 33, 176-184.

Fortelius, M., Mazza, P.P.A., Sala, B., 1993. Stephanorhinus (Mammalia, Rhinocerotidae) of the western European Pleistocene, with a revision of S. etruscus (Falconer, 1868). Palaeontographia italica 80,63-115.

Fosse, P., 1994. Taphonomie paléolithique : les grands mammifères de Soleilhac (Haute-Loire) et de Lunel-Viel 1 (Hérault).. Univiversité d'Aix-Marseille I, (Unpublished $\mathrm{PhD}$ thesis).

Fosse, P., Fourvel, J.-B., 2010. Les mustélidés de Romain-la-Roche (Doubs, France) In: Guérin, C., Malvésy, T., (Eds), L'aven pléistocène moyen final de Romain-la-Roche (Doubs, France). Rev. Paléobiol. 29 (2), 603-611.

Fosse, P., Madelaine, S., Oberlin, C., Cretin, C., Bonnet-Jacquement, P., 2017. Un lion des cavernes (Panthera (Leo) spelaea) exploité au Dryas récent : les données du gisement du Peyrat (Saint-Rabier, Dordogne, France). Paléo 28, 91-115.

Fosse, P., Morel, P., Brugal, J.-P., 2002. Taphonomie et Paléoéthologie des Ursidés Pléistocènes. In: Tillet, T., Binford, L., (Eds.), L'Ours et L'Homme. E.R.A.U.L. Liège 100, 79-101, (Actes du Coll. d'Auberives-en-Royans [Isère], France, 4-6 Nov. 1997).

Fourvel, J.-B., 2012. Hyénidés modernes et fossiles d'Europe et d'Afrique : taphonomie comparée de leurs assemblages osseux. Université de Toulouse-Le Mirail, (Unpublished $\mathrm{PhD}$ thesis)

Fourvel, J.-B., Lateur, N., 2015. Note sur deux mandibules de Pachycrocuta brevirostris Aymard, 1846 du Pléistocène ancien du Sud-Est de la France : la grotte de la Grosse Marguerite (Aiguèze) et l'aven des Trois Pigeons (Nîmes). Paléo 26, $187-200$.

Gagnière, S., 1955. La grande faune de la grotte du Lazaret. In: Octobon, F.E.C., Grotte du Lazaret (Alpes-Maritimes). Premier rapport sur les fouilles effectuées dans le locus VIII de cette grotte. Bull. Mus. Anthr. Préh. Monaco 2, 105-109.

Gamberi Almendra de Carvalho, L., Argant, A., Argant, J., Barth, P., Boudadi-Maligne, M., Boulbes, N., Brugal, J.-P., Caramelli, D., Condemi, S., Crégut, E., Debard, E., Errera, M.G.L., Farre, B., Faure, M., Fernandez, P., Geigl, E.-M., Guérin, C., Harte, S., Jeannet, M., Lateur, N., Mallye, J.-B., Martine, S., Monney, J., Roman, C., Rousselieres, F., Sabaut, M., Valli, A., 2011. L'aven de l'Arquet - Barjac (30) : étude d'un aven piège. Ardèche Archéologie 28, 3-10.

Garrido, G., Arribas, A., 2008. Canis accitanus nov. sp., a new small dog (Canidae Carnivora, Mammalia) from the Fonelas P-1 Plio-Pleistocene site (Guadix, Grenade, Espagne). Geobios 41, 751-761 
Geraads, D., 1992. Phylogenetic analysis of the tribe Bovini (Mammalia: Artiodactyla). Zool. J. of the Linn. Soc. 104, 193-207.

Goubel, H., 2011. Analyse de contour dentaire des Ursidés Pléistocènes et actuels : caractérisation et étude des causes de la variabilité morphologique des dents jugales. Univiversité de Lille I, Sciences et Technologies, (Unpublished PhD thesis)

Grange, T., Brugal, J.-P., Flori, L., Gautier, M., Uzunidis, A., Geigl, E.M., 2018. The evolution and population diversity of bison in Pleistocene and Holocene Eurasia: sex matters. Diversity 10, 65. https://doi.org/10.3390/d10030065.

Gervais, P., 1859. Zoologie et paleontologie francaises. Nouvelles recherches sur les animaux vertébrés, second ed. Arthus Bertrand, libraire-éditeur, Paris, France, (At las).

Griggo, C., 1995. Significations paléoenvironnementales des communautés animales pléistocènes reconnues dans l'abri Suard (Charente) et la grotte Bois-Ragot (Vienne) : essai de quantification de variables climatiques. Univiversité de Bordeaux $\mathrm{I}$, (Unpublished $\mathrm{PhD}$ thesis).

Guadelli, J.-L., 1989 Les Équidés. In: Campy, M., J. Chaline, J., Vuillemey, M., (Eds.), La Baume de Gigny (Jura). Gallia-Préhistoire Paris suppl. 27, 89-95.

Guadelli, J.-L., 1989. Étude taphonomique du repaire d'Hyènes de Camiac (Gironde, France). Éléments de comparaison entre un site naturel et un gisement préhistorique. Bull. A.F.E.Q. 2, 91-100.

Guadelli, J.-L., 1991. Les Chevaux de Solutré. In: Caractérisation et datation des milieux pléistocènes, Ed. du CNRS. Cahiers du Quaternaire Paris 16, 261-336.

Guadelli, J.-L., 1995. Étude des Équidés, In: La Grotte de Pégourié. Caniac-du-Causse (Lot). Préhistoire Quercinoise suppl. 2, 100-147.

Guadelli, J.-L., 1996. Les cerfs du Würm ancien en Aquitaine. Paléo 8 (1), 99-108.

Guadelli, J.-L., 1998. Détermination de l'âge des chevaux fossiles et établissement des classes d'âge. Paléo 10, 87-93.

Guadelli, J.-L., 2007. Étude paléontologique des grands mammifères. In: Raynal, J.P. (Ed.), La grotte de Sainte-Anne I. Le Paléolithique moyen de l'unité J1. Les dossiers de l'Archéo-Logis 3, CDERAD, Laussonne, pp. 163-188.

Guadelli, J.-L., 2011. Les associations fauniques de grands mammifères de la séquence du pléistocène supérieur de Combe-Grenal (Dordogne, France) et la biochronologie des OIS 5 à 3 . In: Proceed. $134^{\mathrm{e}}$ congrès CTHS, Colloque 3.2., Bordeaux (20-25 avril 2009). pp. 199-219.

Guadelli, J.-L., 2013. Historia ossium - Histoire d'os. Univiversité de Bordeaux I, (Unpublished HDr thesis).

Guadelli, J.-L., Prat, F., 1983. Les vestiges d'Équidés de l'Aven de Vergranne (Doubs). Annales Scientif. Univ. de Franche-Comté (Besançon), Géologie 5 (4), 83-92.

Guadelli, J.-L., Prat, F., 1995. Le Cheval du gisement pléistocène moyen de Camp de Peyre (Sauveterre la Lémance, Lot-et-Garonne). Equus mosbachensis campdepeyr nov. ssp. Paléo 7, 85-121.

Guérin, C., 1972. Une nouvelle espèce de rhinocéros à Vialette et dans d'autres gisements du Villafranchien inférieur européen : Dicerorhinus jeanvireti n. sp. Doc. des lab. de Géologie de Lyon 49, 53-150.

Guérin, C., 1973. Les trois espèces de rhinocéros (Mammalia, Perissodactyla) du gisement pléistocène moyen des Abîmes de La Fage à Nouailles (Corrèze). Nouv. Arch. Mus. Hist. nat. Lyon 11, 55-84.

Guérin, C., 1980. Les Rhinocéros (Mammalia, Perissodactyla) du Miocène terminal au Pléistocène supérieur en Europe occidentale. Comparaison avec les espèces actuelles. Doct. Etat es Sc., Univ. Claude-Bernard Lyon(3 vol).

Guérin, C., 1983. Les rhinocéros du Pléistocène moyen du dépôt de Vergranne, Doubs. Annales Scientifiques de l'Univ. de Besançon 5 (4), 47-67.

Guérin, C., 2004. Les rhinocéros (Mammalia, Perissodactyla) du gisement villafranchien moyen de Saint-Vallier (Drôme). Geobios 37, 259-278.

Guérin, C., 2010. Coelodonta antiquitatis praecursor (Rhinocerotidae) du Pléistocène moyen final de l'aven de Romain-la-Roche (Doubs, France). Rev. de Paleobiologie Genève 29, 697-746.

Guérin, C., Dewolf, Y., Lautridou, J.P., 2003. Révision d'un site paléontologique célèbre : Saint-Prest (Chartres, France). Geobios 36, 55-58.

Guérin, C., Faure, M., Argant, A., Argant, J., Crégut-Bonnoure, E., Debard, E., Delson, E., Eisenmann, V., Hugueney, M., Limondin-Lozouet, N., Martin-Suarez, E., Mein, P., Mourer-Chauviré, C., Parenti, F., Pastre, J.-F., Sen, S., Valli, A., 2004. Le gisement pliocène supérieur de Saint-Vallier (Drôme, France). Synthèse biostratigraphique et paléoécologique. Géobios 37, 133-182.

Guérin, C., Patou-Mathis, M., 1996. Les grands mammifères plio-pleistocènes d'Europe. Collection Préhistoire, Paris, France.

Guérin, C., Valli, A.M.F., 2000. Le gisement pléistocène supérieur de la grotte de Jaurens à Nespouls, Corrèze : les Bovidae (Mammalia, Artiodactyla). Cah. Scienc. du Mus. hist. nat. Lyon 1, 7-39.

Hadjouis, D., 1982. Les Canidés de la grotte du Lazaret (Alpes-Maritimes). Étude paléontologique. DEA en Géologie du Quaternaire, Univ. de Paris VI, MNHN.

Heintz, E., 1970. Les Cervidés villafranchiens de France et d'Espagne. Mém. Mus. Nat. Hist. Nat., série C, Paris, France III.

Kahlke, H.D., 2001. Die Rhinocerotiden-Reste aus dem Unterpleistozän von Untermassfeld. In: Kahlke, R.-D. (Ed.), Das Pleistozän von Untermassfeld Bei Meiningen (Thüringen). RGZM, Mainz, pp. 501-555.

Kahlke, R.-D., Lacombat, F., 2008. The earliest immigration of woolly rhinoceros (Coelodonta tologoijensis, Rhinocerotidae, Mammalia) into Europe and its adaptive evolution in Palaearctic cold stage mammal faunas. Quat. Sc. Rev. 27, 1951-1961.

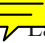

be, B., Guèrin, C., 2005. Réhabilitation de Mammuthus intermedius (Jourdan, 1861), un mammouth (Mammalia, Elephantidae) du Pléistocène moyen récent d'Europe. C.R. Palevol Paris 3, 235-242.

Labe, B., Brugal, J.-P., 2019. Les Proboscidiens. In: Jaubert, J., Brugal, J.-P., Jeannet, M., Kervazo, B., Mourre, V., Thiébaut, C. (Eds.), Coudoulous I : Séquence du Pléistocène moyen en Quercy ou comment l'Animal commande l'Homme et vice-versa, (in press)

Lacombat, F., 2003. Étude des rhinocéros du Pléistocène de l'Europe méditerranéenne et du Massif Central Paléontologie, phylogénie et biostratigraphie. Museum National d'Histoire Naturelle Paris, (Unpublished PhD thesis).

Lacombat, F., 2004-2005. Les grands mammifères fossiles du Velay. Les collections paléontologiques du Plio-Pléistocène du Musée Crozatier - Le Puy-en-Velay. Ann. des Amis du Musée Croizatier 13-14.

Lacombat, F., Abbazzi, L., Ferretti, M.P., Martinez-Navarro, B., Moullé, P.-E., Palombo, M.R., Rook, L., Turner, A., Valli, A., 2008. New data on the Early Villafranchian fauna from Vialette (Haute-Loire, France) based on the collection of the Crozatier Museum (Le Puy-en-Velay, Haute-Loire, France). Quat. Internat. 179, 64-71.

Langlois, A., 2005. Le cheval du gisement Pléistocène moyen de la Micoque (les Eyzies-de-Tayac, Dordogne) : Equus mosbachensis micoquii nov. ssp. Paléo 17, 73-110.

Lovari, S., Scala, C., 1980. Revision of Rupicapra genus. I. A statistical re-evaluation of Couturier's data on the morphometry of six chamois subspecies. Italian Journa of Zoology 47 (1-2), 113-124.

Lister, A., 1990. Critical reappraisal of the Middle Pleistocene deer species "Cervus" elaphoides Kahlke. Quaternaire 3-4, 175-192.

Made, J.van der, 2000. A preliminary note on the rhinos from Bilzingsleben. Praehistoria Thuringica 4, 41-64.

Magniez, P., 2009. Nouvelles données sur le genre Capra Linné, 1758 (Mammalia, Bovidae) du Pléistocène supérieur de la grotte Tournal (Bize-Minervois, France) implications biochronologiques et évolutives. Quaternaire 20, 509-525.

Magniez, P., 2010. Étude paléontologique des Artiodactyles de la grotte Tournal. Étude taphonomique, archéozoologique et paléoécologique des grands Mammifères dans leur cadre biostratigraphique et paléoenvironnemental. Univiversité de Perpignan, (Unpublished PhD thesis)

Magniez, P., Boulbes, N., Brugal, J.-P., 2017. Variations de la taille corporelle chez les ongulés pléistocènes : implications paléoécologiques et taphonomiques. In: Brugal, J.-P. (Ed.), TaphonomieS. EAC, Coll. Sc. Arch, Paris, pp. 454-471.

Magniez, P., Testu, A., Moigne, A.-M., de Lumley, H., 2013. Biochronologie des Mammifères au Quaternaire. Apport des Cervidés du Site Pléistocène Moyen de la Caune de l'Arago (Tautavel, Pyrénées-Orientales, France). Quaternaire 24 (4), 477-502.

Mallye, J.-B., 2007. Les restes de blaireau en contexte archéologique : taphonomie, archéozoologie et éléments de discussion des séquences préhistoriques. Univiversité de Bordeaux I, (Unpublished PhD thesis).

Mallye, J.-B., Guérin, C., 2002. Le gisement Pléistocène supérieur de la grotte de Jaurens à Nespouls, Corrèze, France : Les Mustelidae (Mammalia, Carnivora) Cahiers scientifiques Mus. Hist. nat. Lyon 1, 15-53.

Massilani, D., Guimaraes, S., Brugal, J.-P., Bennet, E.A., Tokarska, M., Arbogast, R.A., Baryshnikov, G., Boeskorov, G., Castel, J.C., Davydov, S., Madelaine, S., Putelat, O., Spasskaya, N., Uerpmann, H.P., Grange, T., Geigl, E.M., 2016. Past climate changes, population dynamics and the origin of Bison in Europe. BMC Biology 14, 93. https://doi.org/10.1186/s12915-016-0317-7.

Masini, F., Lovari, S., 1988. Systematics, phylogenetic relationships, and dispersal of the chamois (Rupicapra spp.). Quat. Res. 30 (3), 339-349.

Mennecart, B., Demiguel, D., Bibi, F., Rössner, G.E., Métais, G., Neenan, J.M., Wang, S., Schulz, G., Müller, B., Costeur, L., 2017. Bony labyrinth morphology clarifies the origin and evolution of deer. Scientific Reports 7 https://doi.org/10.1038/ s41598-017-12848-9.

Michel, V., Shen, C.C., Woodhead, J., Hu, H.M., Wu, C.C., Moullé, P.E., Khatib, S., Cauche, D., Moncel, M.H., Valensi, P., Chou, Y.M., Gallet, S., Echassoux, A., Orange, F., Lumley, de H., 2017. New dating evidence of the early presence of hominins in Southern Europe. Scientific Reports 7 (10074), 1-8. https://doi.org/10. 1038/s41598-017-10178-4

Moigne, A.M., Palombo, M.R., Belda, V., Heriech-Briki, D., Kacimi, S., Lacombat, F., Lumley, de M.A., Moutoussamy, J., Rivals, F., Quilès, J., Testu, A., 2006. Les faunes de grands mammifères de la Caune de l'Arago (Tautavel) dans le cadre biochronologique des faunes du Pléistocène moyen italien. L'Anthropologie 110, $788-831$.

Moullé, P.-E., 1992. Les grands mammifères du Pléistocène inférieur de la grotte du Vallonnet (Roquebrune-Cap-Martin, Alpes-Maritimes). Étude paléontologique des Carnivores, Équidé, Suidé et Bovidés. Muséum National d'Histoire Naturelle Paris, (Unpublished PhD thesis).

Moullé, P.E., Échassoux, A., Martinez-Navarro, B., 2004. Ammotragus europaeus : une nouvelle espèce de Caprini (Bovidae, Mammalia) du Pléistocène inférieur de la grotte du Vallonnet (France). C.R. Palevol 3, 663-673.

Moullé, P.E., Echassoux, A., Lacombat, F., 2006. Taxonomie du grand canidé de la grotte du Vallonnet (Roquebrune-Cap-Martin, Alpes-Maritimes, France). L'Anthropologie 110 (5), 832-836. 
Moullé, P.E., Lacombat, F., Echassoux, A., 2006. Apport des grands mammifères de la grotte du Vallonnet (Roquebrune-Cap-Martin, Alpes-Maritimes, France) à la connaissance du cadre biochronologique de la seconde moitié du Pléistocène inférieur d'Europe. L'Anthropologie 110, 837-849.

Mourer-Chauviré, C., Philippe, M., Quinif, Y., Chaline, J., Debard, E., Guérin, C. Hugueney, M., 2003. Position of the paleontological site Aven I des Abîmes de La Fage, at Noailles (Corrèze, France) in the European Pleistocene chronology. Boreas 32, 521-531.

Olive, F., 2005. Évolution des grands Carnivores Pliocènes et Pléistocènes. Contribution à l'Eurasie et à l'Afrique. Systématique, Biochronologie, Paléobiogéographie et Paléoécologie. Muséum National d'Histoire Naturelle Paris, (2 vol., Unpublished $\mathrm{PhD}$ thesis).

Orlando, L., Ginolhac, A., Zhan, G., Froese, D., Albrechtsen, A., Stiller, M., Schuber, M., Cappellin, E., Petersen, B., Moltke, I., Johnson, P.L.F., Fumagalli, M., Vilstrup, J.T., Raghavan, M., Kornelissen, T., Malaspinas, A.-S., Vogt, J., Szklarczyk, D., Kelstrup, C.D., Vinther, J., Dolocan, A., Stenderup, J., Velazquez, A.M.V., Cahill, J., Rasmussen, M., Wang, X., Min, J., Zazula, G.D., Seguin-Orlando, A., Mortensen, C., Magnussen, K., Thompson, J.F., Weinstock, J., Gregersen, K., Røed, K.H., Eisenmann, V., Rubin, C.J., Miller, D.C., Antczak, D.F., Bertelsen, M.F., Brunak, S., Al-Rasheid, K.A.S., Ryder, O., Andersson, L., Mundy, J., Krogh, A., Gilbert, M.T.P., Kjær, K., Sicheritz-Ponten, T., Jensen, L.J., Olsen, J.V., Hofreiter, M., Nielsen, R., Shapiro, B., Wang, J., Willerslev, E., 2013. Recalibrating Equus evolution using the genome sequence of an early Middle Pleistocene horse. Nature 499 (7456), 74-78.

Orlando, L., Mashkour, M., Burke, A., Douady, C.J., Eisenmann, V., Hänni, C., 2006 Geographic distribution of an extinct equid (Equus hydruntinus: Mammalia, Equidae) revealed by morphological and genetical analyses of fossils. Molec. Ecol. 15 (8), 2083-2093.

Orlando, L., Metcalf, J.L., Alberdi, M.T., Telles-Antunes, M., Bonjeane, D., Otte, M., Martin, F., Eisenmann, V., Mashkour, M., Morello, F., Prado, J.L., Salas-Gismondi, R., Shockey, B.J., Wrinn, P.J., Vasil'ev, S.K., Ovodov, N.D., Cherry, M.I., Hopwood, B., Male, D., Austin, J.J., Hänni, C., Cooper, A., 2009. Revising the recent evolutionary history of equids using ancient DNA. PNAS 106 (51), 21754-21759.

Palacio, P., Berthonaud, V., Guérin, C., Lambourdière, J., Maksud, F., Philippe, M., Plaire, D., Stafford, T., Marsolier-Kergoat, M.C., Elalouf, J.M., 2017. Genome data on the extinct Bison schoetensacki establish it as a sister species of the extant European bison (Bison bonasus). BMC Evolut. Biol. 17, 48. https://doi.org/10. 1186/s12862-017-0894-2.

Pandolfi, L., Cerdeño, E., Codrea, V., Kotsakis, T., 2017. Biogeography and chronology of the Eurasian extinct rhinoceros Stephanorhinus etruscus (Mammalia, Rhinocerotidae). C.R. Palevol 16, 762-773.

Paupe, P., Guèrin, C., Labe, B., Rousselieres, F., 2010. Les mammouths (Proboscidea, Elephantidae) du Pléistocène moyen final de l'aven de Romain-la-Roche (Doubs, France). Rev. Paléobiol. 29 (2), 803-825.

Pereira, E., 2001. Cervus elaphus rossii (Mammalia, Artiodactyla), a new endemic subspecies from the Middle Pleistocene in Corsica. Palaeovertebrata 30 (2-4), 189-213.

Pereira, E., Salotti, M., Bonifay, M.F., 2005. A synthesis of knowledge on the large Pleistocene mammalian fauna from Corsica. In: Alcover, J.A., Bover, P., (Eds.), Proceed. of the International Symposium Insular Vertebrate Evolution: the Paleontological Approach. Monografies de la Societat d'Historia Natural de les Balears $12,287-292$

Patou, M., 1984. Contribution à l'étude des Mammifères des couches supérieures de la grotte du Lazaret (Nice, A.-M.). Méthodes et résultats paléontologiques et paléthnographiques. Univiversité Pierre et Marie Curie, MNHN Paris, (Unpublished $\mathrm{PhD}$ thesis).

Pelletier, M., 2018. Évolution morphométrique et biogéographie des Léporidés dans les environnements méditerranéens au Pléistocène. Implications socio-économiques pour les sociétés humaines. Université Aix-Marseille, (Unpublished $\mathrm{PhD}$ thesis).

Pérez, T., Albornoz, J., Domínguez, A., 2002. Phylogeography of chamois (Rupicapra spp.) inferred from microsatellites. Mol. Phyl. and Evol. 25 (3), 524-534.

Philippe, M., Mourer-Chauviré, C., Evin, J., 1980. Les gisements paléontologiques quaternaires des Causses de Martel et de Gramat (Corrèze et Lot) : faunes et chronologie. Nouv. Arch. Mus. Hist. nat. Lyon suppl. 18, 57-67.

Prat, F., Delpech, F., Cancel, N., Guadelli, J.L., Slott-Moller, R., 2003. Le Bison des steppes, Bison priscus Bojanus, 1827, de la grotte d'Habarra à Arudy (Pyrénées-Atlantiques). Paléo cah. spéc. 5, 1-102.

Prat, F., Thibault, C., 1976. Le gisement de Nauterie à la Romieu (Gers). Fouilles de 1967 à 1973. Nauterie I. Mém. Mus. Nat. Hist. Nat. Paris série Ct. XXXV.

Quillès, J., 2003. Les Ursidae du Pléistocène moyen et supérieur en Midi méditerranéen : apports paléontologiques, biochronologiques et archéozoologiques. Muséum National d'Histoire Naturelle Paris, (t. I, t. II. Unpublished PhD thesis)

Rabeder, G., Hofreiter, M., Nagel, D., Withalm, G., 2004. New taxa of alpine cave bears (Ursidae, Carnivora). In: Actes du $9^{\mathrm{e}}$ Symp. Internat. sur l'ours des cavernes, Entremont-le-Vieux (Savoie, France, Sept. 2003). Cahiers scientifiques Mus. Lyon HS 2, 49-67.

Rivals, F., 2004. Les petits bovidés (Caprini et Rupicaprini) pléistocènes dans le bassin méditerranéen et le Caucase : étude paléontologique, biostratigraphique, archéozo- ologique et paléoécologique. B.A.R. Archeopress Oxford, Internat. Series 1327, $1-252$

Rivals, F., 2006. Découverte de Capra caucasica et d'Hemitragus cedrensis (Mammalia, Bovidae) dans les niveaux du Pléistocène supérieur de la Caune de l'Arago (Tautavel, France) : implication biochronologique dans le contexte du Bassin Méditerranéen. Géobios 39, 85-102.

Rivals, F., Blasco, R., 2008. Presence of Hemitragus aff. cedrensis (Mammalia, Bovidae) in the Iberian Peninsula: biochronological and biogeographical implications of its discovery at Bolomor Cave (Valencia, Spain). C. R. Palevol. 7, 391-399.

Rodríguez-Varela, R., Tagliacozzo, A., Ureña, I., García, N., Crégut-Bonnoure, , Mannino, M.A., Arsuaga, J.L., Valdiosera, C., 2015. Ancient DNA evidence of Iberian lynx palaeoendemism. Quat. Sc. Rev. 112, 172-180.

Rousseau, J., 2008. Contribution à la connaissance d'Equus hydruntinus et intérêt biostratigraphique de ces petits Équidés. Univiversité de Bordeaux, (Unpublished Master thesis).

Rouzaud, F., Soulier, M., Brugal, J.-P., Jaubert, J., 1990. L'igue des Rameaux (Saint-Antonin-Noble-Val, Tarn-et-Garonne). Un nouveau gisement du Pléistocène moyen. Premiers résultats. Paléo 2, 89-106.

Salotti, M., Bellot-Gourlet, L., Courtois, J.Y., Dubois, J.N., Louchart, A., Mourer-Chauviré, C., Oberlin, C., Pereira, E., Poupeau, G., Tramoni, P., 2000. La fin du Pléistocène supérieur et le début de l'Holocène en Corse : apports paléontologique et archéologique du site de Castiglione (Oletta, Haute-Corse). Quaternaire 11 (3), 219-230.

Sanz, M., Daura, J., Brugal, J.-P., 2014. First occurrence of the extinct deer Haploidoceros in the Iberian Peninsula in the Upper Pleistocene of the Cova del Rinoceront (Castelldefels, Barcelona). C. R. Palevol 13 (1), 27-40.

Sardella, R., Petrucci, M., 2012. The earliest Middle Pleistocene Crocuta crocuta (Erxleben, 1777) at Casal Selce (Rome, Italy). Quat. Internat. 267, 103-110.

Schreve, D.C., Keen, D.H., Limondin-Lozouet, N., Auguste, P., Santisteban, J.I., Ubilla, M., Matoshko, A., Bridgland, D.R., Westaway, R., 2007. Progress in faunal correlation of Late Cenozoic fluvial sequences 2000-4: the report of the IGCP 449 biostratigraphy subgroup. Quat. Sc. Rev. 26, 2970-2995.

Sirakov, N., Guadelli, J.L., Ivanova, S., Sirakova, S., Boudadi-Maligne, M., Dimitrova, I., Fernandez, P., Ferrier, C., Guadelli, A., Iordanova, D., Iordanova, N., Kovatcheva, M., Krumov, I., Leblanc, J.C., Miteva, V., Popov, V., Spassov, R., Taneva, S., Tsanova, T., 2010. An ancient continuous human presence in the Balkans and the beginnings of the settlement of western Eurasia. The Lower Pleistocene example of Lower Palaeolithic in Kozarnika cave (North-western Bulgaria). Quat. Internat. 223-224, 94-106.

Slimak, L., Lewis, J.E., Crégut-Bonnoure, E., Metz, L., Ollivier, V., André, P., Chzrazvez, J., Giraud, Y., Jeannet, M., Magnin, F., 2010. Le Grand Abri aux Puces, a Mousterian site from the last interglacial: paleogeography, paleoenvironment, and new excavation results. J. of Arch. Sc. 37, 2747-2761.

Testu, A., 2006. Étude paléontologique et biostratigraphique des Felidae et Hyaenidae pléistocènes de l'Europe méditerranéenne. (Sites de la Caune de l'Arago, Orgnac 3, le Portel-Ouest, Bize-Tournal, l'Hortus, la Crouzade en France, la Cova de l'Arbreda en Espagne, Karaïn E en Turquie). Université de Perpignan, (Unpublished $\mathrm{PhD}$ thesis).

Theobald, N., Szymanek, C., 1963. Le crâne de Rhinocéros à narines cloisonnées des grottes de Rigney (Doubs). Annales Scientifiques de l’Univ. de Besançon 17, 98-113.

Tournepiche, J.F., 1982. Le gisement paléontologique würmien de la grotte du Quéroy (Charente). Bull. S.P.F. 79, 99.

Tournepiche, J.-F., 1984. Faunes et industries antérissiennes de la grotte d'Artenac (Charente). C.R. Acad. Sc. Paris 298II (9), 423-428.

Tournepiche, J.F., 1996. Les grands mammifères pléistocènes de Poitou-Charentes. Paléo 8, 109-141.

Tsoukala, E., Bonifay, M.-F., 2004. The Early Pleistocene Carnivores (Mammalia) from Ceyssaguet (Haute-Loire). Paléo 16, 193-242.

Ureña, I., Ersmark, E., Samaniego, J.A., Galindo-Pellicena, M.A., Crégut-Bonnoure, 三 Bolívar, H., Gómez-Olivencia, A., Rios-Garaizar, J., Garate, D., Dalén, L., Ar-

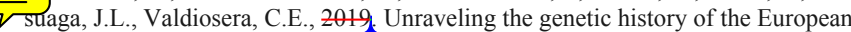
wild goats. Quat. Se.(in press),

Uzunidis-Boutillier, A., 2017. Grands herbivores de la fin du Pléistocène moyen au début du Pléistocène supérieur dans le sud de la France. Implications anthropologiques pour la lignée néandertalienne. Université d'Aix-Marseille, (Unpublished $\mathrm{PhD}$ thesis).

Uzunidis, A., Brugal, J.P., 2018. Les Grands Herbivores (Bovinés, Equidés, Rhinocérotidés, Proboscidiens) de la fin du Pléistocène Moyen : la couche 9 de Coudoulous II (Lot, Quercy, Sud-ouest France). Paléo 29, 223-249.

Valensi, P., 1994. Les grands mammifères de la grotte du Lazaret, Nice. Étude paléontologique et biostratigraphique des carnivores. Archéozoologie des grandes faunes. Musuem National Histoire Naturelle Paris, (I, II, Unpublished PhD thesis).

Valensi, P., 2009. Évolution des peuplements de grands mammifères en Europe méditerranéenne occidentale durant le Pléistocène moyen et supérieur. Un exemple régional : Les Alpes du Sud françaises et italiennes. Quaternaire 20 (4), 551-567.

Valli, M.F., 2004. Les Cervidae du gisement Pliocène supérieur (Villafranchien moyen) de Saint-Vallier (Drôme, France). Geobios 37, 191-232. 
Valli, M.F., Caron, J.B., Debard, E., Guérin, C., Pastre, J.F., Argant, J., 2006. Le gisement paléontologique villafranchien terminal de Peyrolles (Issoire, Puy-de-Dôme, France) : résultats de nouvelles prospections. Geodiversitas 28 (2), 297-317.
Vercoutere, C., Guérin, C., 2010. Les Bovidae (Mammalia, Artiodactyla) du Pléistocène moyen final de l'aven de Romain-la-Roche (Doubs, France). Rev. Paléobiol. 29 (2), 655-696. 